\title{
Economic Effects of China's Accession to the WTO on the Asia-Pacific Economies
}

\author{
HUNGGUE LEE \\ Department of Insemastinal Trade, Konkuk University
}

\begin{abstract}
China's entry to the World Trade Onganization (WTO) will bate an infuence on the trade patterns of the Asia-Pacific economies in two ways. The first ane is a static impact effect that to be realized immediately after China's atression to the WTO. The second is a dynamic ome that will ocrue as a result of China's internal poling reform. For this dynamic effect to necur; bowever, China needs to solve several problems associated uith political and systemic constraints.' In this paper, a simple ztneral equilibrium model of China is set up to determine both the static and dynumic effuts and the gravity equations of China's Asia-Patific neighbors are estimated to assess the welfare effects of China's accession to the WTO. This paper raises a question regarding the ecrmmic effects of Chinu's entry to the WTO, that is, whether China's accessisn to the WIO will contribute to overall regional grouth rather than benefiting only a small number of countries for only China). In light of the analysis in this paper, the ansuer to this question is affirmative. As long as the Asia-Pacific Economic Cooperation (APEC) economies remain open, not only China itself, but also the other members will benefit from Cbina's accession to the WIO. Another question this paper deals with is the static and dynamic effects of China's arcession to the W7O on the otber APEC members. China's accession to the WTO will bave uffects on its oum policy-making. The internal reform following its accession to the WTO will enbance China's total facter productivity (TFP) as the changes imposed by the WTO will remave barriers to efficiency and increase imestment in buman and physical capital.
\end{abstract}

Part of this paper was presented at the "Trilateral Conference" jointly hosted by Beijing Union University, Californa State Lniversity at Fresno, and Konkuk University, in Beijing, September 11-12, 2002. It has been revised for presentation at the "Joint Meeting of Korcan Economic Societies" in Scoul, February 13-14, 2(X)3. The aurhor is graceful to Professor Hongyul Han for valuable comments and ocher participants in the session for the APEC: Studies Assoriation of Koreal.

Direcr all cotrespondence to Honggue Lee, Professor of International Trakde, Konkuk IIniversicy, Seroul 143-701, Korea; Tel: 82-2-450-3647; Fax: 82-2-3436-6610, E-rail: hongleé(j)konkuk.ac.kr 


\section{IN"TRODUCTION}

A fer tifteen long years of negoriation, China has gained encry to the World Irade Organization, which signals that China is ready to cake its place amongst the global ecomonic powerhouses and that it prepared to assume the responsibjlity of piaying by its rules. China's accession to the WTO provides opportunitics and challenges for both China and the rest of the world in general, and the Asia-Pacific econonies in parricular. Market access and tariff reduction will offer porentially enormous comnecrial opportunites for foreign firms. (hina's new WTO membership will increase the amount of bilateral trade flow with its trading partners, as China becomes mure open to new imports and obrains good prospects for new growth in various sectors of the economy.

The sorld aconomy has already benefited from the expanding rade relationshipp with china over the past ewenty ycars. The outside world will continut io gain from Chinats accession to the WTO. China is une of the world's largest markets. Chinas shate of the worla's imports was $3.1 \%$ pereent in 2007 . It is rhe second largest market in Asia behind Japan whtusc world import share was 5 4t percent in 2001 . Fxports w (hina will provide jobs in those scctors that are key parts of the engine of growth in many cisurntries. It is true that the cutside world would incur short-term losses in some sectors such as frotwear and textiles, but these short-term dislocation costs should be wighed against the long-cem benefits ascribable to the uperation of comparative advantage. It is norable that China will be aking jobs primarily from those countries in Latin America and Soutleast Asia.

With unprecedented access to China, upportunitics in scctors such as agricliture will expand remarkatsly. A range of other industries will expand as well, notably financial services, telecommunications and information technology. It is also important to note the benefies to foreign consumers who have access to inexpensive imports. China's entry into the WTO will help foreign consumers to enjoy low-price imports trom China such as roys, sporting goods, foocwear, clothes, plastic soods, suitcases, and furniture.

China has already become the world's steventh largest trading country, yet it has avoided the constraints posed by the international trating system, by remaining outside the system. What has caused the (hinese government to comply with the scandards of the international erading system? Chind has agreed to the eerms of the WTO to take advantage of the increased forcign competition as a mans of accelerating its domestic conomic reform progsam.? With the help of increaseo international competition, (hind can look forward to facilitating the process of transforming inefficient state-owned-enterprises. At the same time, as Peter Nolan 2001$)$ purs it, China can

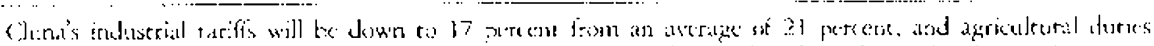

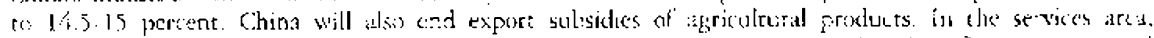

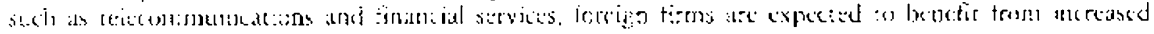
marker aciess

Dikias K. Lardy isur) i. 
take advantage of market opening to catch up wich the world's leading corporations. China has resorted to industrial policies with a view to building large corporations comparable to those based in more advanced countries. While China's large firms had achieved huge advances by the late 1990s, global firms improved revolutionarily, leaving China's large firms even further behind the global leaders than before its economic reform.

By strengthening the private sector, China's entry into the WTO will help invigorate the position of the private enterprises and allow many Chincse to work outside of the state system. The presence of mote forcign firms operating in China will enhance competirion in the markerplace, which will raise productivity and income. This will help improve both working and environmental conditions in China. Getting resources into the hands of the Chinese citizenry is also the best way for then to arriculate demands and press for reform over the long term.

China's commitment to open its markets requires a more profound rransformation of its economy. While China's membership to the WTO will contribute to achieving higher standards of living for its citizens and increased growth for its economy, it will bring pressure on the Chinese government to abide by the rulcs of the global trading system. China will have to undertake further economic reforms that will change the coututry into a more market-oriented one.

China's accession to the WTO will inevitably induce policy changes. The benefits of an appropriate economic policy cannot be exaggerated. Parente and Prescott (200) show how policy differences across countries lead to differences in the total factor productivity (TFP) among them, which in turn explains differences in income. They define aggregate production as the maximum output that can be produced given not only the technology constraints but also the policy constraints on the use of technologies. With increasing factor mobility, therefore, it is the differences in policies not in the stock of useable knowledge or physical capital that help explain the differences in income levels across colintries. If the Chinese government policies change: to facilitate enhancing the TFP, welfare effect ensuing the China's entry to the WTO will be reinforced.

Given these external and internal welfare effects of China's accession to the WTO, two sources of the economic effects can be inferred. From the viewpoint of the outside world, the first one is a direct effect of China's integration into the world trading system, which is attributable to market expansion and is expected to ripple through the outside world. The sccond one, an indifect effect, feeds back from its effect on the productivity and output changes in China resulting from the transformation of the economic structure and policy measures.

By focusing on these two sources of the effects that China's entry to the WTO will have, this paper looks into the implications of China's accession to the WTO for the trade relationship between China and the outside world, particularly in the

\footnotetext{
It is defined as the maximum output that can lx proxluecel given the quantities of the aggrega:e injuns. Sce Parente and Prescote (20130) chatster 6 for details.
} 
context of China's relationship with its Asia-Pacific Economic Cooperation (APEC) neighbors.

The rest of the paper is organized as follows. Scction $1 \mathrm{f}$ will first assess the current condition of China as a major trading partner of the Asia-Pacific region, which indirectly indicates the excent of the effects that China's entry to the WTO will have on its neightors. Then it will provide some implications of China's accession to the WTO. Then Section III will discuss the welfare effects of China's accession to the WTO on the Asia-Pacific economies. Section III will also provide a simple general equilibrium analysis of the counterfactual shocks ensuing China's entry to the WrO. Then it will employ the estimation results of the gravity model to assess the effects on the trade fluws of China's neighbors in the Asia-Pacific region. Section IV will conclude the paper.

\section{CONTEX'TS AND IMPLICATIONS OF CHINA'S ACCESSION TO THE WTO}

The effects of China's entry to the WTO on the Asia-Pacific economies will be determined by those variables that have been instrumental in shaping the trade relationship between China and its neighbors in the Asia-Pacific rcgion. Among others, China's current economic condirions have important implications for that trade relationship and so are the various constraints and problems that Chind's economic system faces.

\section{A. Current Economic Conditions of China}

\section{Economic Fundamentals 5}

Despite a prolonged slowdown in major power's economies, China has showed a remarkable cconomic performance. In terms of economic growth, price stability, export performance, forcign reserve holdings, and trade balances, China's records tave been exceptional. Morcover, China's economy possesses a great resilience. When the financial crisis afflicted the Asian economies, some experts predicteal that China would end up in the list of the victions. That prediction proved wrong. Instead, China was able to take advantage of the Asian economic crisis. This indirectly shows that China has raken a different path from that of the other Asian countries in pursuit of its economic development.

China's economic progress owes much to its vast growth potential. One of the most important sources is political stability. The Chinese government has relied on socialist elitism in order to maintain its political stability. Linder strong political lead-

The foilowing is bised on APEC: (20)1). 
ership, it has been able to carry out unwavering open-door policies. For example, having faced the threat of economic downturn, China has continually carried out active fiscal policy along with expansionary monetary policy. It has cut down interest rates eight times during the past four years and has issued bonds worth US\$3.8 billion in order to finance social overhead capital projects.

Another source of growth is the foreign firms stationed in China. They have taken the lead in expanding China's exports. As long as the foreign direct investment flowing into China continues to increasc, these firms will continue to enhance China's economic resilience. It is very likely that the flow of foreign direct investment will continue to increase because, with an almost unlimited supply of labor, China is ablc to provide labor to foreign investors for modest wage rates.

Still another source is scale and network economies. Undoubtedly, China is one of the few countries that can accomplish scale economies in its own market. Accomplishing economies of scale within a country has not been possible even for either Russia or Japan. For the European countries, it was not until the passage of the Single European Act that they bxgan to look forward to realizing the economics of scale throughout Europe. At the same time, overseas Chinese merchants make available business networks that can be intensively used to expand export markets, facilitate capital movement, and technology transfer.

Finally, two exogenous factors have contribured to the sustained economic growth: self-sufficiency in food production and energy supply and relacively stable political relations with the United States. Self-sufficiency in food and energy has made it possible for China to increase its net foreign reserve holdings, while the warm relations with the United States have induced the World Bank and Asia Development Bank to provide financial resources to China's public investment. 'I'he United States has provided a market for China's exports and allowed its production facilities to be moved to China.

\section{External Economic Relations and Trade Policy Regimé}

As one of the largest trading countries in the world, China now accounts for about 4.3 percent of the world's exports and 3.8 percent of world imports in 2001. Given the fact that Chima's world export and import shares were both less than one percent in 1980, it is remarkable that China has become a major trading partner of the outside world ovet the years. China's export share in the APEC's total exports has also increased from 2.6 percent in 1980 to 9.3 percent in 2001, while its import share in the APEC's total imports has incteased from 2.7 percent to 7.8 percent. China's exports and imports have been growing faster than any other economies in the region.

In line with its open door policy, China has continuously lowered its tariff rates.

${ }^{5}$ The foljowing is based on Chinas 2001 Individual Action Plan. 
The simple average tariff rate was brought down to 23 percent from 36 percent as of the end of 7996 . It was further reducet down to 17 percent in 1997 and so 16.7 percent in 1999. As of 2001 , China's simple average tariff rare was i5.3 percent. With the tariff adjustments made on $3 / 62$ items (1 15 - 8 -digit) which account for 49 percent of all eariff lines, China's inport tariff lines have cone to cover 7111 items (HS 8-digit). With its accession to the WTO, (hina has promised to bind all the tariff lines and reduce the tariff rates in accordance with the time schedule described in the terms of entry. At the same time, in order to enhance the stability and cransparency of China's tariff policy, the Chinese government instituted legal procedures that stipulate how to identity items suitable for imposing tariffs, and that specify how to adjust the tarift races.

The (hinese government has also made efforts to reduce non-tariff measures since 1492. As of the end of September 2001, only $351 \mathrm{HS}$ tariff lines (HS 8-digit) were left among those non tariff measures. 'The accession io the WT() forces (hina to phase out mose of the non-tariff measures in accorclance with its commitments to the world trading body. $M$ s of the end of Scptember 2001 , the non-tariff measures were applied to 235 import lines (HS 8 digit). Among then fí products (HS 8-digit) were subicer 6 import license in (hind and 72 items (HS 8 -digit) were included in the aategory of other non-tariff measurts.

\section{B. Constraints Facing China}

While with the accession to the WIO (hind is nust likely to continue to matintain its high conoumic growth, this is condirioned on its success in removing various constraints it faces in the transition of China's economy. In particular, the accession to the WTO will pur pressure on (hina's hybrid "dual-track" system in which strong politica! controls and growing market influtences otsexist.

\section{Dual-Track Econemy}

In carrying out the economic reform, China has been resorting to the "dual-track" system in which a market track and a plan track cocxist in the state industrial sectur. This system relies on "marginal" liberalization with "marketization" on the one hand and reduction of bureaucratic barriers to the state-owned enterprises on the other. In the dual-track system, the speed of liberalization can be adjusted ro overcome the polirical constraines associared with price liberalization. The speed of liberalization is a funcrion of these political constraincs.

The dual-track system hinders a smoots change to an open economy unless at highly authoritarisin folitical systcm is werhauled. (hina's accession to the WrTO will work as public pressure against the dual track, which will force profunod changes

Lı (19); ;ind: 
in the dual-track system. The dual-track system is frone to corruption. In this system, firms contract a fixed amount of deliveries between them at planned prices fixed and sell all residual output produced by firms at markec prices, with all profits from this residual output accruing to firms. ${ }^{8}$ Since privileged buyers have the right to purchase goods at the planned price that is lower than the market price, they have an incentive to resell the goods on the market and cash in rents. The dual-track system has also contributed to increased diversion by officials in the plan track of the production under the planned quotas by reducing the transaction costs of selling goods diverted from the state enterprises. The new rents the dual-track system gencrates have been a source of the public discontent in China, where popular support for the reforms works as a precondition for their sustainability?

\section{Soft Budget Constraint}

State ownership involves inefficient allocation of resources. At the same time, past reforms have left the state industrial sector littered with ineffective regulations. 10 The cost of the state-owned enterprises is hard to defend. Investment is often wasted. State enterprises produce goods that are not sold. The soft-budget constraint problem refers to a situation in which the socialist planner cannot get rid of the moncy-losing state firms. Although this problem is found in both socialist and capitalist economics, it has been a more important concern in socialist economies. ${ }^{11}$

The soft-budget constraint has made it difficult to restructure the unprofitable state owned enterprises, stop paying subsidies to the money-losing firms, reallocate resources across sectors, and keep the government expenditures under control. Cutting subsidies is one of many ways to "harden budget constraints," which will reverse the consequences of the soft-budget constraint. A more realistic way of dealing with this problem is to look at the effect of the increased incentives on productivity growth. "Ihe "hardening of budget cunstraint" can be defined as a matter of institutional design rather than a matter of policy choice. ${ }^{2}$ In this regard, China's accession to the WTO is expected to bring in changes that will result in the hardening of budyet constraint. ${ }^{\text {: }}$

The state industrial sector is still indispensable to China's economic and social stability as it employs more than 45 percent of the workforce. 14 However, with easy sources of growth potential running out, China cannot afford to have luxury not to overhaul its state sector. It has to let the marketplace hold sway over allocating

\footnotetext{
Roland (2000), 132).

Roland (2000) 148).

1: See the Eionomist $(2000)$ for a pessinistic interpretation of Chisla's reform process.

11 R(slurst $(2000) .2: 3)$.

Koland $2000,214.215)$ provides discussion on soft budger constraints seen as a dinamic, endogenous, commitnetst problem.

"It is a matter of controversy whether China changes as the result of WT() accession. See the Eiononitit (20) 2 ) for disseuting opinion.

:t Th! Rismontu! (2002, 4).
} 
resources efficiently.

\section{Chailenges Ahead}

\section{Liberalization}

Trade agreements are an cxternal commitment that promises trade policy reforms. Both regional integration and WTO accession obligate China to accelerate its economic reform. China has already taken measures to fulfill its share of obligation roward achieving the goals of the APEC process and has made a great effort to liberalize its trade and investment regimes over the years. Nevertheless, the WTO disciplines will be much more comprehensive and forceful. While the APEC itself is in the form of a forum in which the members voluntarily undertake trade and investment liberalization, the WTO is an entity that rules over its members regarding trade policy, dispute setclements, and trade negociations. 'The policy measures that had to be taken by China on its participation in the APFC process are not as significant as those that have to be taken in the wake of its entry to the WTO. ${ }^{15}$ The accession to the WTO, thereforc, will play another important, but more critical role in China's liberalization process.

With China's entry to the WTO, significant changes are expected to be inevitable in China's conduct of foreign trade and investment policies. China's entry to the WTO will expedice its internal policy retorm process, which should raise China's 'IF'. Parente and Prescott (2000) assert that a country expericncing a permanent change in its political cconomic institutions is able to converge to a significantly higher balanced growth path. Policy danges contribure to enhancing IFP so that the policy differences across countries account for a major pare of the differences in international incomes. ${ }^{16}$ With almost identical rates of return on investment between countries and global availability of knowledge stock, the policy differences are instrumental in explaining the TFP differences. For example, Japan was far below its long run growth path before an increase in the TFP was made possible by the vecupying American military forces. When they imposed major changes in Japan's policical and economic institutions, however, Japan was able to converge to a higher growth path. ${ }^{i ;}$

While in genctal policy determincs how technolugy is used or how its use is constrained, it will influence, particularly in case of China, how fast the transition frorn the dual-track to the market mechanism is made. Policy differences lead to the TFP differences because they change the aggregate production function of the cconomy through their effects on the use of technology. The aggregate production function is defined as the maximum amount of output that can be produced given both the

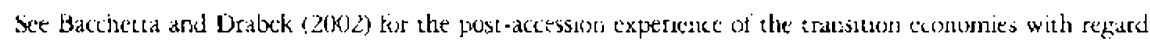
to the effect of WTO atcessitin or policy reforms.

"For a toral capital share in GIJP eglal to $2 / 3$, a given relative TFP differente resules in relative steady-state output differences erual to a fartor io: 3 .

Parence and Prescott (20)i), Ch 5). 
technology constraints and the constraints on the use of technology ascribable to policies. ${ }^{18}$ When a government protects those who are tied to a particular production process with vested interests, constraints on technology unfavorably alter the aggregate production function. Changes in policy regime induced by the WTO will reduce down barriers to enhancing firm's efficiency and investing in human and physical capital. The transition from the two-track to an entitely market-based economy is expected to accelerate after the WTO accession. The ensuing adjustment costs will be considerable, but should be more than the offset by efficiency gains. Such transition would be highly valuable, if China is able to change its domestic economic policy to enhance market accessibility, stamp out corruption, and improve governance.

\section{Palitical Reform}

It is troublesome, however, that the biggest challenge to the Chinese economy is not so much the structural economic reform as the sluggish political reform. The structural economic problems undoubtedly pose a threat to the Chinese economy: the liquidity problem in the financial sector, the increasing public debt, and the consequences of the economic downturn in the Lnited States are all likely to aggravate the structural economic troubles. China is not alone in suffering from the aftermath of strucrual adjustment, and is nor necessarily behind the other countries in coping with it. However, what is more critical in the long run is to consolidate the commitment of China's political leadership to the transition toward the market economy. Structural adjustment with a drastic political reform will make it possible for China to enhance its economic efficiency and to secure social stability. Moreover, it will rid China of the rampant corruption resulting from the abuse of power and establish the rule of law. Cortuption has been responsible for lowering economic efficiency and has contributed to deepening economic inequality.

It is also ominous that the communist leadership does not want to lose control over its vested interests cven though it has acquiesced to adopt the market principle marginally. In that case, China cannor fully take advantage of the market opening and reforms. For example, although thousands of the state-owned enterprises (SOEs) are suffering from debts, they are exempted from the reforms since the party leadership and local officials want to retain them as devices for sustaining their vested interests. If China does not take measures to reform the SOEs, the benefits of China's accession to the WTO will not come to full fruition. Moreover, since the ownership structure has a great influence on profitability and productivity, the reform of the SOLs is no longer a problem of firms only, but also a matter of governance structure and power and a control over the economic resources and vested interests. Although capital strucrures, taxes, and welfare burdens have had a significant effect on the performance of the Chinese enterprises, the SOE's productivity growth has lagged behind that

18 Parente and Prescott (2000, 82). 
of the private firms with ocher ownership structures. ${ }^{14}$

\section{Discussion}

The question now is whether China will be able to keep up its rerrarkable economic performance in the future so that its impact on the tradle patterns of the Asia-Pacific economies may persist. Is it possible for China to sustain high economic groweth after its accession to the WTO? Despite complicated problems, cautious optimism prevails. It is based on several positive indicators concening policy retorms. ${ }^{20}$ first, the Chinese government's medium-to-long-term structural adjustment plans seem to have worked. They have succeeded in sustaining price stability and expanding growth potential. Second, Chira's external economic relationship is also promising. 'Ihe coming Beijing Olympic Games as well as China's accession to the WTO will bolster final demand and contribute to income growth. Third, in the composition af rhe final demand, the share of consumption expenditure is increasing. China has relied on foreign import demands in its management of aggregate demand. China's sxport oriented development strategy has succeeded in attracting capital from Hong Kong and Taiwan that are readily combined with the vast supply of labor in China. On top of it, the emergence of middle-income households will boost China's dumestic purchasing power. Consumption expenditure will constitute a solid component of the final demand in the future. Fourch, labor productivity will be increased by the infusion of high skilled labor educated abroad into China. lochnoctats, forcign coducated experes, and Chinese residents in Hong Kong and Taiwan all provide a pool of competitive human capital that will enhance the toral factor protus rivity. Fiffh, China is the second largest country in terms of foreign reserve holdings, which amount to alsout US\$ 240 billion. (hina is second only to Japan and is virtually frec from the danger of foreign debt crisis. Sixth, (hina is alout to establish several "local axcs of growth" throughout the country, which will be spread out from the eastern coastal provinces toward the western inland areas. In the past, the regional development pattern was characterized by the inflow of foreign direct investment and mobilization of rural surplus labor. With market opening and reforms, the coastal provinces have attracted most of forcign direct investmest and migrant labor into themselves. The differences in recurns to capital and wage rates between the coastial arcas and other provinces have concributed to the growtl disparity. Thus, a balanced regional derelopmont resulting from the established local axes of growth will help build up the foundation for an ever increasing industrial and consumer demand.

\section{Trade Relationship in the Asia-Pacific Region}

The trade structure of the Asia-Pacific region will determine the extent wo which

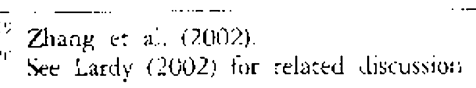


the effects of China's accession to the WTO are felt on its neighbors in the Asia-Pacific region. The trade-related features of the Asia-Pacific economies shape the conditions through which the spillover effects are transferred.

\section{Intra-regionul Irade}

Diversity and interdependence characterize the Asia-Pacific economies. While these cconomies differ in their stages of development, income levels, market size, and openness, they are experiencing a growing interdependence among themselves. This increasing intcrdependence is unambiguously indicated by the increasing amount of trade flows within the region. In particular, the tatio of intra-regional trade in the Asia-Pacific region is much larger than that of the North American Free Trade Agreement (NAFTA), and even larger than that of the European Union.

It is important to note that the Asia-Pacific region has become not only a vast market for its own exports, but also a principal source of its imports. The increasing ratio of regional exports and imports indicates the growing importance of the AsiaPacific community to itself relative to the outside world. At the same time, the rate of change in this direction is accelerating. Given the large differences in income levels and absorprion capability, incrcasing interdependence is remarkable.

\section{Bilateral Trade Flows}

The composition of intra-regional trade is also changing. ${ }^{21}$ In the majority of the cases, each member's share of the imports from the other members in its total amount of imports is increasing relative to that of the exports. This increase in the individual share reveals that each member's dependence on the other members as its source of resuurces becomes incrcasingly more important than its dependence on them as an income source. The fact that the importance of regional trade partners as the import sources is increasing implies that the reverberating effects of China's accession to the WTO on its trading partners will be substantial since China has already become an important source of the imports for the other member economies.

On the other hand, economic diversity in the region has caused the member economies to have different export patterns in different markets, which implies that their production (diversification) patterns are different. The developing economies in the Asia-Pacific region have experienced a unique process of industrialization in which a leading country's comparative alvantage in certain sectors of manufacturing moves from the leading country to others. 22 In consequence, manufacturing has spread out all over the region, and the less developed area in the region has adopted specialization patterns in accordance

21 See Lee and Ryou (1997) for hurther discussion.

2.? This advantage initially allows firms in the leading country to pay higher wages than those in other countries. However, with in increasing demand for their goods, they can no longer afford to pay higher wages. Overtitac, firms have to move their plants to another country as they find it profuable to set up manufacturing base elsewhere. 
with changing comparative advantage.

\section{Intra-indastry 'Trade}

The pattern of comparative advantage is not the only mechanisen that explains the trade fows across botders. Trade based on increasing returns to scale (IRS) and product differentiation explains trade in the idencical industries particularly when the differences in factor proportions are not very large between countries. The Grubel-Lloyd index ${ }^{23}$ is a useful tool for assessing the degree of such intra-industry trade flows.

As shown in Table 1, across each of their respective trading partners in the region, Peru has the lowest average Grubel-Lloyd index with a value of 0.038 , and Hong Kong has che highest value of (0.579. The fact that Hong Kong has the highest index can be attributed to its special teade relations with China: Hong Kong has long played a significant role in providing an outlet for China, whereas China has provided Hong Kong with access to its production base. Countries with lower indices are expected to have a substantial amount of the trade based on comparativc advantage, while those with higher indices are more likely to engage in the trade based on product differentiation and scale economies. 24

China's Grubel-Lloyd indices is just below the average of the APEC members included in the data set. Under the assumption that the excluded APEC members are retarively labor-abundant, however, China's is likely to be above average in the complete data set. This implies that the effects of China's accession to the WTO in the Asia-Pacific region will be fallen "significantly" on those countries with the Grubel-Lloyd indices similar to that of China. The top notch of those countries whose specialization partern rests on comparative advantage will be as much affected as the lower end of those countries whose specialization is hased on scales economies and product differentiation. Yet this conjecture should be taken with caution, since index is not a perfect indicator. Inconsistency in industrial classification and the presence of trade in intermediate goods

The (imbel-lokyd index indicates the extenc to which incta-industry trade based on increasing recurns to scale (IRS) and proxlict differentiation enables a country to simultaneously impor and expore varisties of a partiknlar produce. This index is calculated from the share of intra-industry trade :al total tade.

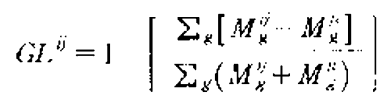

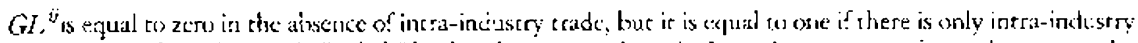
crade. Thus, if the bilateral Gruhel-Lloyd indexes are relacivecy large in a grouj of samples, rt can be intered that a relatively large proportion of bilateral crade in this group is two-way cride in detferentared products. See Frenctt and Keller (200)?, 288).

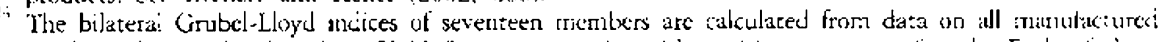

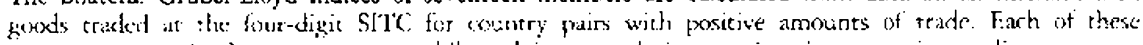
seventees councries has uf to cwenty bilatecal import relations against its respective trating partners.

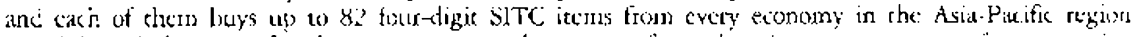

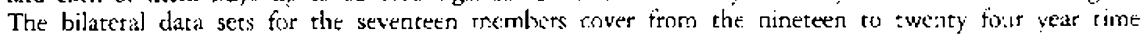
periuds. 
may prevent the indices from exactly measuring the share of trade attributable to IRS and product differentiation.25

TABLE 1. AVerage GRLBel-LloYd INDices

\begin{tabular}{|c|c|c|c|c|c|}
\hline & \multicolumn{2}{|c|}{ Grubel-Lloyd lndex } & & \multicolumn{2}{|c|}{ Grubel-Lloyd Index } \\
\hline & $?$ & $?$ & & $?$ & $?$ \\
\hline Australin & 0.226 & 0.151 & Malaysia & 0.228 & 0.200 \\
\hline Canada & 0.153 & 0.147 & New Zealand & 0.150 & 0.132 \\
\hline Chile & 0.053 & 0.073 & Peru & 0.038 & 0.065 \\
\hline China & 0.190 & 0.161 & Philippines & 0.157 & 0.156 \\
\hline Hong Kong & 0.579 & 0.208 & Singapore & 0.285 & 0.202 \\
\hline Indonesia & 0.115 & 0.113 & Ithai & 0.168 & 0.166 \\
\hline Japaun & 0.153 & 0.128 & Tajwan & 0.195 & 0.171 \\
\hline Korea & 0.202 & 0.171 & U.S. & $0.2 \% 1$ & 0.194 \\
\hline Mexicu & 0.139 & (1. 162 & Avcrage & 0.195 & 0.153 \\
\hline
\end{tabular}

\section{ASSESSING 'THE SPILLOVER EFFECTS ON THE ASLA-PACIFIC ECONOMIES}

China's entry to the WTO will have an influence on the trade patterns of the AsiaPacific economics in two ways. The first one is a static impact effect to be realized immediately after China's accession to the WTO. The second one is a dynamic effect that results from the internal policy reform. Before the dynamic effect is to be fully realized, however, several problems have to be solved. Political and systemic constraints have to be addressed as discussed in the previous section. In this section, both the static impact effect and the indirect dynamic effect will be incorporated into the analytical framcwork for assessing the welfare effects of China's accession to the WTO. 'To that end, a simple general equilibrium model of China is set up and the gravity equations of China's Asia-Pacific neighbors are estimated.

\section{A. A Simple Gencral Equilibrium Model}

A simple general equilibrium model referred to as the "1-2-3 model" based on Microsgft Excel 26 is used to capture a rough picture of the short-term shocks and the long-term policy changes ensuing China's accession to the WTO. ${ }^{27}$ This model is

\footnotetext{
25 Evenetr and Keller (2002, 288).

20 It is a trademark of Microsoft Corporation.

${ }^{27}$ The moded draws on Devarajan et al. (199)7). Linlike the more sophisticated (GE molels, this model cannot properly deal with the mulri-sector econony. Yer some of the results obcained from multi-sector
} 
based on a structure consisting of one-country, two-productive sectors, and three goods. and it has thee actors: a producer, a household, and the rest of the work. 'The country in the model is assumed to be small in the world markets.

The two producive sectors, tradable groods sector and non-tradable goods sccor, are specified into a constant clasticity of transformation (CET) function with eransiormation elasticity. They produce two commoditics: an export grond. E, which is sold to foreigners and a domestic good, $D$, which is sold domestically. The domestic production possibility frontier, a CET function, shows the combinations of $E$ and $D$ that the economy can supply which is identical to real GDP.

One representative household reccives all income and consumes a composite conjonodity made up of a domestic good, $D$, and an import. $M$. Imports and domestic goods are assumed to be imperfect substirures, which satisfy the Armington assumption. 'The composite commodity is given by a constant clasticisy of substitution (CES) function of $M$ and $D$ with substitution clasticity? Consurace is maximizing utility or maximizing the: compositc commodity.

Alternatively, the "1-2-3" model can be referred to as a progranming problem in which social welfare is maximized with respect ro $M, E, D$ under the constraints of technological feasibility, balance of trade, and domestic equilibrium. A graphical versiun of this model is shown in Figure 1. The transformation function deternines the equilibrium amounts of the domestic and export goods $(E / D)$ at the point of tangency with a given price ratio $p^{\prime \prime} / p^{\prime}$. The balance of ade is obtained on the 45-degree line through the origin. With the inflow of foreign capital, the balance-ofrade line, however, shifts up by the amount of capital movernent. The corrposite commodity is constructed as a function of the domestic and imported goosds ( $A$ and $D$ ). Their equilibrium amounts $(M / D)$ are detcrmined by the tangency berween the ios lifference curves and the "consumption possibiliry frontier" at a given price ratio $p$ " : $p$ ".

Graphical representation facilitates understanding the direct effect of the shocks and the indirect effect of the policy changes following China's cntry to the WTO. For simplicity, suppose that the shocks (the policy changes) arce taking place "sequentially" over time: for example, reduction in trade barriers, inflows of capital, ind changes in institutional artangenents in this order. linst, if China lowces its rade batrices in accordance with the terms of entry, the impact effect of such tariff reform will come in the torm of the changes in the relative price of goods and the allocation of resources. Then, with greater economic growth potential in prospect. Chira may gain arcess to the friendlier world capital markets and see in increased amount of foreign direct investment. The: inflow of foreign capital induced by the initial trade reform shifts up both the balance of the trade line (from $B$ to $B^{\prime}$ ) and the consumprion possibility frontier or the production possibility frontice of the composite commolity $Q=F(M, D d)$ from the onc containing $C$ to that containing $C$.' Finally, if (hina accelerates and completes internal policy reform in compliance with the W'IO's re-

inciels can be anticipated hese. 
¿quirements, this will climinate productive incffeciency and move the production possibility frontier $X=G(E, D s)$ out to the Pareto frontier ${ }^{28}$ from the one containing $P$ and $P^{\prime}$ to that containing $P . "$

Different equilibrium points can be traced out with the progression of the sequential policy changes and external shocks. First, consumption equilibrium points obtain at the points of tangency between the social indifference curves and the consumption possibility fronticrs. The short-run equilibrium immediately following a tariff reform is attained at $C$. Ihe short-to-medium run equilibrium with the capital inflow is reached at $C$.' 'The medium-to-long run equilibrium after the completion of the internal reform is established at $C$.' The production equilibrium points obtain at the tangency between the production possibility frontiers and $p / p$. The short-run production poinc is atrained at $P$, the short-to-medium run production point at $P$; and the medium-to-long run production poine at $P$." Note that the production possibility frontier does not shift until the internal policy reform is taking place, so that both $P$ and $P^{1}$ are on the same pruduction pussibility frontier.

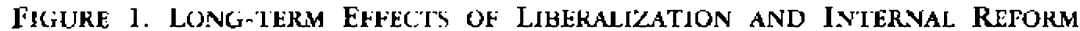

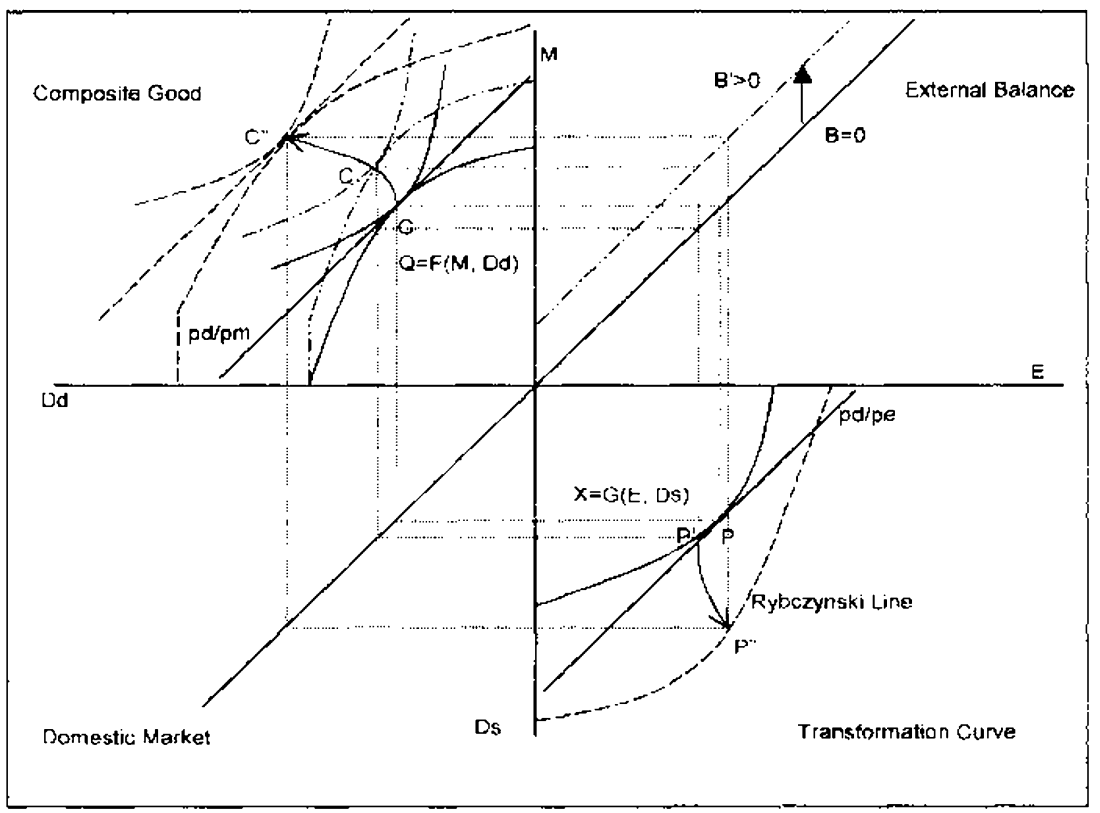

B. Nunerical Analysis

The external strocks and policy changes in the " $1-2-3 "$ model can be numerically

\footnotetext{
It means that the portential production possibility fruntier obtains when the sectoral reallocation of resources is completed in accordance with the improvernent in the TFP after liberalizatios.
} 
evaluated in Fxel, a spreadsheet program. Setting up a model in an Excel prugram involves four steps: defining parameters and variables, entering data, assigning initial values to parameters and variables, and specifying equations. ${ }^{29}$ The Solver command cat be used to carry out numerical simulations.

The equations of the model and their variables and parameters shown in Appendix $A$ are self-explanatory. Most parameters and variables are calibrated to reproduce the origioal data as a solution to the model. Exceptions are clasticities and policy barrier prameters. The elasticities of the production and consumprion fronticrs are assumed 1.25 and 0.75 respectively. These numbers are arbitrarily chosen without any theortical support. Yet the value of policy barriers parameter is based on the estimation of the TFP improvement in China's SOEs done by Li (1997). He shows that the growth in the TFP attributable to the reform in China's SOEs explains almost 73 percent of their tocal output growth. 30 It can be inferred from this study that, had it not been for the policy reform, 73 percent of the output growth would have disappeared. In a sense, the reform removed the barriers to the TFP improvenent and made it possible to cnhance the IFP and output growth. Positing on the assumption that WTO accession will reproduce the same effect as that of the past reform in the SOFs, the numerical valuc of the policy barrices parameter in the present model is set to be 0.35 to replicate the number 0.73 as barriers to the TFP imptovement. However, since the reform process takes time, the CF.T funcrion is assumed to contain the barriers-to-TFP improvement parameter only in the medium-to-long run model.

\section{Simulations}

In the assessment of the economic effects of China's entry to the WTO, three scenarios characterized by different time span are considered. The first one involves the impast effect of a rariff reform only. The second one inclutes the astditional effect of an increase in the intlow of private capital induced by China's reform prospect. The third one allows simulaneous changes in all three variables: a tarifi reform, an increased inflow of foreign capital, and an internal policy reform ro be completed over time. The tariff reform is carried out through a reduction in the tax collection rate (import tariff divided by imports), which is to be cut by fifty percent. 'I the inflow of (apital is to increase by fifty percent in anticipation of a tariff reform and other reform prospects. The internal policy reform removes the barricrs to the TTP improvement. 31

The simulation results presented in Table 2 show that most of the coconomic effects are realized in the medium-to-long run and that the internal policy reform is much

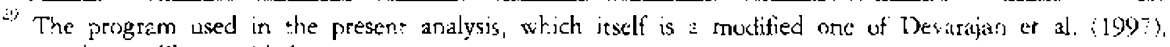
(an) be readify provided on request.

i) $1 . j(199) 7,1081$ ?

Another secnaro may include the government budget consteaint. in whict subsidies to the state sectot are recuce!. This possibioity is not considered in the followitg sine there is no difference in the method of amaiysic. 
more influential in bringing about substantial changes in macrocconomic indicators. Indeed, it is contingent on the success of the ensuing internal policy reform removing bartiers to the TFP that a cariff reform together with the inflow of foreign capital succeeds in accomplishing economic growth and stability.

In the short run, a fifty percent reduction in the tariff collection rate induces 2.02 percent increase in imports and 1.86 percent increase in exports. It will also increase consumption by 0.64 percent, but decrease aggregate savings by 0.85 percent, to which government savings reduction due to the loss of tariff revenue contributes substantially. Investment decreases due to the reduction in aggregate savings. All in all the total income is reduced by 0.95 percent. The real exchange rate is depreciated because of a decrease in the price of the domestic good.

TABLE 2. EFFECTS OF LIBERAIIZATION AND INTERNAL REFORM (Percentage Changiss from thre hevehmark Valufgs)

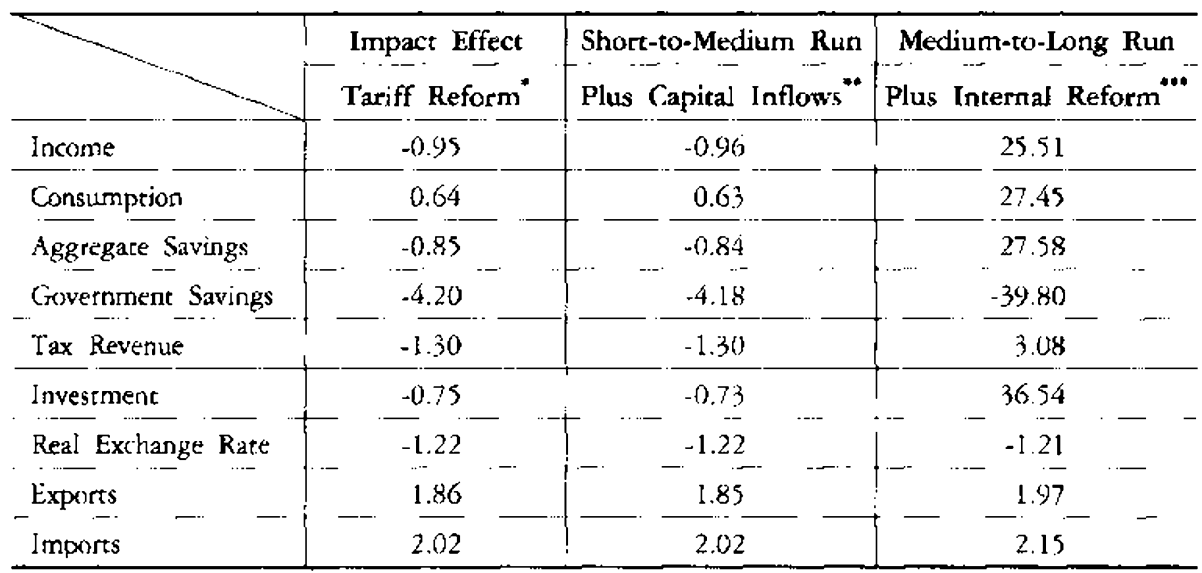

Note: * A fifty percont reduction in the tariff collection rate.

-* A fifty percent reduction in the tariff collection rate and a fifcy percent increase in private capital intlows.

**. A fify percent rediktion in the tariff collection rate, a fify percene increase in capital inflows, and a complete remowal of barriers to Tt:P improvement.

The inflow of foreign capital following the tariff reform does not change the shortrun result very much. The increase in the flow of foreign capital is realized through a fifty percent increase in net profits and dividends, whose value is less than five percent of the total imports. The relatively small size of foreign capital inflow brings in a relatively insubstantial change in the macto economic indicators in comparison with the tariff reform. In this model, the inflow of capital may possibly cause "Dutch Disease" in which the non-tradable secror expands at the expense of the tradable sector. Both exports and imports decrease slightly, while the demand for and supply of domestic goods increases. Yet, as shown in the following, there is only a slim chance for this possibility in the case of China.

Unlike the tariff reform and the inflow of capital, the internal policy reform changes 
the simulation results much morc substantially. Aggregute income increases 25.5 percent over time. Savings and investment increase 27.6 percent and 36.5 percent respectively. Consumption increases 27.5 percent. The non-tradable sector (domestic good production and consumption) increases much faster than the cradable sector (exports and imports) expands, so that the relative share of the tradable sector decreases in comparison with the first two scenarios. In orher words, the internal policy reform may result in "pseudo-I Dutch-discase," as it is set ro renove much rnore effectively the inefficiencies in the stare industry or the "plan-track" of the duab-track economy than the tradable scctor that pursues a market-rack of the economy. Consecuently the state industry expands much faster than that of the marker economy in the third scenario.

\section{Gravity Equation Analysis}

While the simulation results are suitable for assessing the direct and indireet effects of Chinas entry to the WTO on itself, they are not for assessing the spillover effects on China's neighbors in the Asia-Pacific region. Gravity equation analysis is a method used here to estimate the spillover effects of China's entry to the WTO on its neighbors. The gravity equation model based on the monopolistic competition model is used, which is better than the standard trade model in explaining the trade patterns of the world in which a multitude of goods are traded across countries. Under the assumption that demand is identical and homothetic across councries, this gravity model explains tracte in these varieties as intra-industry trade in which a variecy produced in any country is serut to all the other countrics in proportion to their GI)P.

For the estimation of the gravity equation, seventecen sets of pand dat: have been used. 32 Among shem, China's has the minimum number of ubservations, 263, and Japan's has the maximum of 108 observations. The structure of the regression model is an "effecrs" model in which variarions across countries or time are capturest in the changes in the intercepts. The fixed effects and ranitom effects for both one-and twofactor models along with the pooled dassical OLS model have been estimated. For presentation, however, only the best of these five types of estimates is reported for each counery. The estimates of the wo-factor (time and country effects) model are not selected. because the one-factor (country effect) model does provide "better" estimates. The two-factor model is not usually applied in practice for two scasons. First, it incurs the loss in the degree of freedom, and, second, time trend can be beteer represcrited by other variables than the dummy variable. "The one factor model also gets the better of the OJS modet, as evidenced by its Iagrange multiplier test results. Iarge values of the Lagrange multiplict statistic favor onc of the one-factor models against the classical regression wich no country specific effects. At any significance level, i

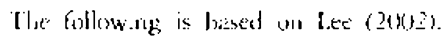

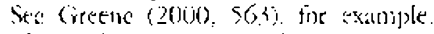

The probativicy vilute of this statistic or signilicance ievell is practically zetes. 
the one-factor model is favored. The choice between the fixed effects and variable effects models have been made based on the Houseman test statistics at the 5 percent significance level. When the Houseman test statistic is sufficiently high, the results of the fixed effects model are chosen.

The regression equation relates the amount of bilateral trade flows to the sum of GDPs, the product of relative country sizes (or size "dispersion"), the degree of "product differentiation" (or the "putative" number of varieties), transport costs deflated by the exchange rate variability, and exporter's price relative to importer's. Statistical significance of the estinates has been tested at the 5 percent level.

\section{Regression on Bilateral Export Flous}

The log sum of the countrie's GDPs is expected to have a positive sign and be equal to 1. The regression estimates of this coefficient for all countries selected are positive, but they are not always close to 1. China, Indonesia, Malaysia, Thailand, Chile, and Mexico' exports (in the descending order) are very responsive to the expansion of the bilateral market size. However, for Peru, its estimate is statistically insignificant.

The product of the country shares is supposed to have a positive sign as the volume of trade increases with the increasing similarity between the two trading partners. Except for Thailand, the estimates on this term are all positive and significant. Regression results bear out what Helpman and Krugman (1985) have predicted.

Eleven out of seventeen countries have negative signs on the number of the variety (produce differentiation) term along with positive signs on the relative price (comparative advantage) term. Negative sign on the number of the variety (product differentiation) term complies with what has been predicted. However, only six of them are statistically significant. Australia, Chile, Korea, Mexico, and New Zealand have negative coefficients, but theirs are not statistically significant. Only China, Indonesia, Japan, Malaysia, Thailand, and the Lnited States have a statistically significant negative signs. On the other hand, Canada, Hong Kong, Peru, the Philippines, Singapore, and Taiwan have unexpected positive signs on the product differcutiation term, while they have negative sign on the telarive price term. These estimates cxcept Peru's are all statistically significant. For these countries, comparative advantage scems to prevail in explaining a major portion of their trade.

Bilateral trade flows are expected to fall as distance increases. This is one of the pillars of the gravity equation. Yet the regression results show that distance does not necessarily matter. ${ }^{35}$ The effect of distance is not separacely reported in the estimation result tables. Instead, the combined cffect of distance and exchange rate variability on the bilateral trarle flows has been reported. It is supposed to represent the "price" effect. In theory, it is obvious that "depreciation" should increase exports, while "appreciation" decreases exports. Moreover, exchange rate instability will impede the flow

3) A sumilar result has becn reported in Evertict and Keller $(200) ?)$ 
of trade across countries. Yet, the combined term does not show any substantial effect on the bilateral trade flows. In the cases of Chile, China, New Zealand, Peru, and Taiwan, the estimates have the wrong sign. Except for Peru, not all the estimates are statistically significant. Peri's case makes the only genume exception. The reason why Peru has a statistically significant, and a positive sign san be attributed to sudden discuptions in its exchange rate that the regime experienced during the late $1980 \mathrm{~s}$ and the early 1290s. Small changes in the exchange rates would not bave made any difference to the amount of rrade volume.

\section{Regression on Bilateral Import Flows}

Estimation results of the tegression equation based on bilateral import flows show that all the individual country estimates (except Thailand's) on both the combinedmarket term and the size-dispersion term have the expected positive signs. Thailand is an exception, but its estimatc on the size-dispersion term is not statistically significant,

As is the case with bilatcral export flows, the estimates of product differentiation and comparative advantage terms have turned out to have opposite signs to each other. In twelve out of seventecen cases, the product differentiation term has the expected negarive sign. Australia, Canada, Chile, China, Japan, Indonesia, Mexico, New Zealand, Peru, the Philippines, Singapore, and Taiwan have negative signs on the product differentiation term. Yet the estimates of the five countries (Australia, China, Japan, New Zcaland and the Philippines) are statistically significant, while those of the other countries are not.

Except for the Philippines, distance combined with the exchange rate variability doxs not seem to have any significant influence on bilateral import flows. The estimates have a negative sign on the term for bilateral distance augmented by the price variability. Fxcept for Chile, China, and Indonesia, they are all statistically insignificant.

Estimation results on the product differentiation and relative price terms differ a fot, depending on what trade flows data are used. Nine countries change their signs on these rwo terms when different dependent variables are used. Canada, Peru, the: Philippines, Singapore, and 'Taiwan's coefficients of the product differentiation term (the relative price term) are positive (negative) when regressed on bilateral export flows, but they have negative (positive) values when regressed on the bilateral import flows. The opposite is true of Korea, Malaysia, Thailand, and Lnited States They have changed their sign on the product differentiation term from a negative une to a positive one. Australia, Chile, China, Indonesia, and Japan have retained their negative sign on the product differentiation term, while Hong Kong has a positive sign regardless of the data types used.

While the estimation results of the other countries are given in Appendix B, China's trade flow equations are shown in Table 3 . It can be inferred from Table 3 that the bilateral cxport flows between China and its trading partners are very responsive to the scale and dispersion effects as well as to comparative advantage. The same 
is true of bilateral import flows, but to a lesser degrec. China's trade flows also show that there exists substitutability between product differentiation and comparative advantage in explaining trade paterns.

Table 3. Trade flows of China

\begin{tabular}{|c|c|c|c|c|c|c|c|c|}
\hline \multicolumn{2}{|c|}{ China } & \multirow{2}{*}{$\frac{\log \left(Y_{1}+Y_{1}\right)}{4.72}$} & \multirow{2}{*}{$-\frac{\log (\mathrm{SiSj})}{4.24}$} & \multirow{2}{*}{$\frac{\log \left(Y \mathrm{j} / \mathrm{Pj}^{*} \mathrm{C}\right)}{-3.14}$} & \multirow{2}{*}{$\begin{array}{l}\text { Distance } \\
0.00\end{array}$} & \multirow{2}{*}{$\begin{array}{r}\log (\mathrm{Pi} / \mathrm{Pj}) \\
\quad 3.02\end{array}$} & \multirow{2}{*}{ Constant } & \multirow{2}{*}{$\frac{\text { Adj } R 2}{\text { Sample }}$} \\
\hline \multirow{2}{*}{$\mathrm{X}_{\mathrm{ij}}$} & Coeff. & & & & & & & \\
\hline & t-ratio & 29.71 & 11.08 & -8.07 & 0.89 & 7.65 & & 263 \\
\hline & & \multirow{2}{*}{$\log \left(Y_{i}+Y_{j}\right)$} & \multirow{2}{*}{$\log (\mathrm{SiSj})$} & \multirow{2}{*}{$\log \left(\mathrm{Yi}_{\mathrm{i}} / \mathrm{Pi}^{*} \mathrm{q}\right)$} & \multirow{2}{*}{ Distance } & \multirow{2}{*}{$\log \left(P_{j} / P_{j}\right)$} & \multirow{2}{*}{ Constant } & Adj R2 \\
\hline & & & & & & & & Sample \\
\hline \multirow{2}{*}{ Mij } & Coeff. & 2.63 & 1.21 & -1.38 & 0.00 & 1.35 & 8.99 & 0.86 \\
\hline & t-racio & 12.95 & 3.65 & -3.06 & 0.10 & 3.01 & 3.26 & 263 \\
\hline
\end{tabular}

\section{E. Spillover Effects}

The gravity equation is used to assess how the effects of China's accession to the WTO are spilted over to its Asia-Pacific neighbors through the changes in the flows of exports and imports. The changes in GDPs, exchange rate variability, and other aggregate variables caused by China's entry into the WTO should be plugged into the estimated gravity equation in order to calculate the spillover effects. These effects summarized in Table 4 are calculated as the sum of the direct effect ascribable to the changes in exports (imports) themselves and the indirect effect ascribable to the changes in exports (imports) associated with the changes in income.

In the short nun, most of China's neighbors can anticipate their cxports to China to increase moderately. The export growth rates are ranging from 0.86 percent (Taiwan) to 1.70 percent (Japan and Indonesia). Yet, if China's internal reform is accelerated by its entry to the WTO, the long-term effect will be felt most significantly in Taiwan (29.01 percent), Canada (26.43 percent), Peru (24.15 percent), and Chile ( 22.78 percent). The spillover effects are felt differently depending on the time horizon. In the short run, the impact effect will contribute to expanding the rradable sector substantially. However, in the long run, the relative size of the tradable sector will reduce pressures from import competition and change the import pattern of China.

The import growth rate in the short run is the highest in 'Ihailand. On the other hand, impores from China are decreasing in Japan ( -0.20 percent) and Mexico ( -0.15 percent). In the long tun, imports from China will increase most rapidly in Mexico (34.84 percent), Thailand (29.82 petcent), and Malaysia (28.72 percent). However, Peru's imports from China will decrease by 6.32 percent.

With the growth rate changes in exports and imports, the rate of balance of trade improvement can be shown as in the B-O-P Improvement column in Table 4 . In 
the short nu, Peru (-0.86), Thailand ( -0.66 percent), the Lnited States ( -0.56 percent) and Hong Kong ( -0.42 percent) will experience a deterioration of balance of trade. Yet, in the long run, it is Ihailand ( -26.17 percent), Malaysia (-20.36 percent), and Mexico (-14.28 percent) that will suffer the most. On the other hand, in the short run, balance of trade is expected to improve in yapan (1.90 percent), Australia (1.51 percent) and Mexico (1.33 percent). In the long run, it is Peru (30.47 percent), the Philippines (19.03 percent), and Chile (15.65 percent) that are expected ro improve the trade balance most substantially.

Table 4. SPIl.iover EFrlets on The Asia-Pacific Economies (PlikClNTAGE Chanike)

\begin{tabular}{|c|c|c|c|c|c|c|}
\hline & \multicolumn{2}{|c|}{ Expott (irowth } & \multicolumn{3}{|c|}{ Import Growth } & \multirow{2}{*}{$\begin{array}{c}\text { B-O-P Improvernet } \\
\text { S-Run SMRun MI.Run }\end{array}$} \\
\hline & S-Run & SMRun MI.Run & S-Run & SMRun & MLRun & \\
\hline Australia & 1.36 & 11.70 & 0.05 & $0.0 ;$ & 19.02 & $1.51,1.53$ \\
\hline Canladi: & $1 .(1)$ & $1.17+26.43$ & (3.01 & $-1) .01$ & 23.13 & $107 \quad 1.18$ \\
\hline Chile & 100 & $(1.50 \quad 27.78$ & i). 63 & 10.60 & $7: 23$ & 15.65 \\
\hline $\mathrm{H}_{\mathrm{i}, \mathrm{ng}} \mathrm{Kung}$ & 1.63 & 10.83 & 203 & 201 & 5.91 & $-(t) \therefore ?$ \\
\hline Indonesia & 1.70 & 1.60 & (3.53 & 0.51 & 18.71 & $-1,30$ \\
\hline Jipan & 1.70 & (i). 31 & $-i) .20$ & -0.22 & 1.4 .23 & $1.91 \quad-2 \div$ \\
\hline Korea & 1.24 & 16.47 & 1.41 & 143 & 17.31 & 0.84 \\
\hline Mexice: & 1.18 & 2056 & $-(1.15$ & -0.17 & 3481 & -1.2 .28 \\
\hline Malaysia & 1.28 & 1.37 & 1.32 & 1.30 & 28.2 & $20.30:$ \\
\hline Nicw 7ealand & $1 \therefore$ & 13.27 & (1.1) & 0.18 & $6.7 \mathrm{i}$ & 6.76 \\
\hline Peru & $1.1:$ & $1.10,29.15$ & 1.97 & 1.96 & -6.32 & -11.86 \\
\hline Philipysuses. & 1.3\% & 20.81 & 1.07 & 1.06 & 1.78 & 1903 \\
\hline Singiapore & 1.42 & 16.11 & $0.9 ?$ & $0.9 !$ & 8.20 & 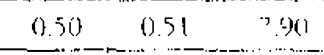 \\
\hline Thlail:and & 1.46 & 1.46 & 2.12 & 2.09 & 29.82 & 26.17 \\
\hline Triwan & 0.86 & 96.61 & 1.01 & $0.9 \%$ & 19.100 & 10.61 \\
\hline [1.5. & 1.44 & $1+65$ & 1.98 & $1.9^{7}$ & $\therefore$ : 1 & .0 .51 \\
\hline
\end{tabular}

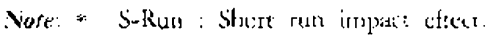

* SMRun: Shusr-ti-modium run etfect

*x* Ml.Run: Medium-lo-long ras: eftec:.

\section{CONCLUSION}

Positing an optimistic scenario of China's future political and eronomic development. this paper has raken on several questions associated with the effects of China's accession to the WTO. In light of the analysis in this paper. it is likely that China's atcession to the WTO will contribute to overall regional (or workd) growth rathet than benetiting 
only a small number of countries (or only China). As long as the APEC economies remain open, not only China itself, but also the other members will benefit from China's accession to the W'IOO.

'This paper has also assessed the extent of the effects both static and dynamic that China's accession to the WIO will have on the other APEC members. As evidenced by the empirical results, this can be substantial. The answer to this question depends on whether China's accession to the WTO will have at effect on its own policy-making, which this paper assumes to be positive. The internal reform following its accession will enhance China's TFP as the changes imposed by the WTO will remove barriers to efficiency and investment in human and physical capital. This presumption is hardly defensible unless the transition from the two-track economy to the full-fledged market economy is successfully completed in China.

Yet this paper leaves some questions unanswered. The first one is to explain how the policy differences lead to the IFP differences: that is, how policy can affect the aggregate production function of the economy. Instead, the mechanism through which policies are decided is assumed away. The second one is how to deal with the political economy considerations affecting China's conomic relatjonship with the outside workd. As it can be inferted from the fact that the terms of China's entry to the WTO allow the United States and other industrial nations to "manage" trade with China, this is a legitimate concern. Left alone, manipulation such as the application of special antidumping and safeguards is likely to diminish the potential benefits from China's accession to the WTO.

\section{REFERENCES}

Anderson, James A. 1979. "A Theoretical Fouldation for the Gravity Equation." American Economic Review 6): 106-116.

Asia Pacific Economic Cooperation. 2001. Econsmic Outlonk. Singapore: APEC Secretariat.

Baccherca, Marc and Zdenck Drabek. 2002. "Effects of WTO Accession on Policy-making in Sovereign States: Prdiminary Lessons from the Recent Experience of l'ransition Countries." WTO Staff Working Papcr, DERD-2002-02.

The Ex'rumist. 2000. "A Survcy of China: Now Comes the Hard Part." April 8. 2002. "A Survey of China: Out of Puff." Junc 15.

Evenet, Simon J. and Wolfgang Keller. 2002. "On Theories Explaining the Success of the Gravity Equation." Journal of Political Economy 110 (2): 281-316.

Federal Reserve Board. 2002. Statistics: Rele ases and Historical Data, G.5A, (http:/www. federalreserve.gov/releases).

Green, William H. 2000. Econometric Analysis. 4t $4^{\text {to }}$ Edition, Now Jersey: Prentice Hall Inc.

Haveman, Jon. 2002. International Trade Data, Iseful Gravity Model Data, Distance Measure. (http:/www.macmaster.edu/research/economics/PAGE/HAVEMAN/Trade. 
Resources/ Tradelata.html \# Gravity)

Helpman, Elhanan. 1987. "Iriperfect Compctition and International Tradc: Evidence from Fourtecn Industrial Councries." Joumal of the Japanese and International Economici. 1: 62-81. Helpinan, Elhanan, and Paul R Kugrman. 1985. Market Structure and Foreign Trade: Increasingr Retums, Imperfect Competition, and the International Economy. Cambridge: MTT Press.

International Monetary Fund. 2000. World Economic Outiok Database, Washington, D.C.; International Monetary Fund.

Lardy. Nicholas $\mathrm{R}$ 2002. Integrating China into the Global Economy. Washington, D.C.: Brookings Institution Press.

Lee, Honggue, 2002. "Estimation of the Irade-Patterns of the Asia-Pacific Economics Using the Gravity F.quation." Guk-Je-Tong-Sang-Yenn-Gu(in Koreun) 7(2): 147/171. Lee. Honggue and Jaj-Won Ryou. 1997. "Regional Integration and Liberalization in the Asia-Pacific." Korea Institute for Internarional Economic Policy, Policy Paper 97-02. Li, Wci. 1997. "The Impact of Economic Reform on the Performance of Chinese Statc Enterprises, 1980-1989." Joursal of Political Rionomy 105: 1080-1106.

Nolan, Perer. 2001. China and the Global Buinesi Ravulution. New York: Padgrave Macmillats. Parente, Stephen I., and Edward C. Prcscott. 2000. Barriers to Riches. Cambridge: MTT Press.

Summers, Robert, and Alan Heston. 1991. "The Penn World Tahle (Mark 5): An Extended Set of International Comparisons, 1950-1988." Quarterly Juamal of Economis 106: 327-68. Supachai, Panitchpakdi and Mark Cifford. 2002. China and the WIO: Changing China, Changing World 'Trade. New York: Wiley, John \& Sons, Incurporated.

World Bank. 2001. Trade and Production, 1976-1999. CD-ROM. Washington, D.C.: World Bank.

7hang, Anming, Yimin 7hang and Ronald Zhao. 2002. "Profitability and Productivicy of Chinese Indusrrial Firms: Measurement and Ownership Implications." China Economic Revitu 13: 65-88. 


\section{APPENDIX A: THE “1-2-3" MODEL}

\section{TABle A.l, EQuations}

\section{Real Flous}

1. CET Production Possibility Frontier

$$
X=A_{X}\left(\delta E^{\rho}-(1-\delta) D_{s}^{\rho}\right)^{\frac{1}{\rho}} \text { or } X=A_{X}\left(\delta_{1} E^{\rho}+\left(1-\delta_{1}\right) \Psi^{\rho} D_{S}^{\rho}\right)^{\frac{1}{\rho}}
$$

2. CES Consumption Possibility Frontier

$$
Q=A_{Q}\left(\delta_{2} M^{\mu}-\left(1-\delta_{2}\right) D_{s}^{p}\right)^{\frac{1}{\rho}}
$$

3. Equilibrium Relative Supply

$$
\frac{E}{D_{S}}=\left(\frac{\left(1-\delta_{1}\right) p^{e}}{\delta_{1} p^{d}}\right)^{\rho_{2}^{1}} \text { or } \frac{E}{D_{S}}=\left(\frac{\left(1-\delta_{1}\right) \Psi^{\rho} p^{e}}{\delta_{1} p^{d}}\right)^{\frac{1}{p-1}}
$$

4. Equilibrium Relative Demand

$$
\frac{M}{D_{D}}=\left(-\left.\frac{\delta_{1} p^{d}}{\left(1-\delta_{1}\right) p^{m}}\right|^{\frac{1}{1-\rho}}\right.
$$

5. Aggregate Domestic Demand $Y D=C+I+G$

\section{Nominal Flows}

6. Income Equation

$$
Y=p_{x} X+p_{q} \text { (transfer) }+(\text { exchange rate)(remittances) }
$$

7. Savings

$$
S=s_{Y} Y \text { (exchange rate) } B+S_{G}
$$

8. Consumption

$$
C=\frac{\left(1-t_{Y}-s_{Y}\right) Y}{p_{t}}
$$

9. Government Revenue

$$
T=p_{m}^{w} t_{m} \text { (exchange rate) } M+p_{e} t_{e} E+p_{Q} t_{s} Q_{D}+t_{Y} Y
$$

\section{Prices}

10. Import Price

11. Export Price

12. Sales Price

$$
\begin{aligned}
& p_{m}=\left(1-t_{m}\right) p_{m}^{W} \\
& p_{e}=\frac{1}{\left(1+t_{m}\right)} p_{e}^{W} \\
& p_{t}=\left(1+t_{s}\right) p_{q}
\end{aligned}
$$


13. GDP Deflator

I.1. CPI

15. Numeraire (Exchange Rate)

$$
\begin{aligned}
& P_{s} E+P_{d} D_{s} \\
& p_{x}=\quad X \\
& p_{a}-\frac{P_{m} M+F_{d i} D_{d}}{X} \\
& \text { exchange rate }=1
\end{aligned}
$$

\section{Equilibrium Conditions}

16. Domestic Good Market

$$
\begin{aligned}
& D_{i}-D_{s}=0 \\
& Q_{i i}-Q_{s}=0
\end{aligned}
$$

17. Composite Commolity Market

18. Current Account Balance

$$
C A-p_{m}^{\prime \prime} M-p_{*}^{*} E \quad \text { transfer - remittances }
$$

\begin{tabular}{|c|c|c|c|c|c|c|c|}
\hline \multirow[t]{9}{*}{1} & National Accounts & \multicolumn{3}{|c|}{ Yuan (BLN) Output=1, 3} & Fiscal Account & Yuan (BL. & Output $=1$ \\
\hline & Ourzut (Value Added) & 9393.3 & 1.00 & & Revenut: & $16(1900$ & $0 .$. \\
\hline & Wages & 1253.2 & 0.76 & & Mon-Tax & $1: 360$ & $0,0,1)$ \\
\hline & GLl' (Market Valuc) & 1)? 170 & $1.11 \mathrm{i}$ & & Current Expenducure & 1 198.10! & (1) 6 \\
\hline & Private Corsumetior. & 4588.8 & 0.48 & & Gininls \& Strices & 10695 & 0.1 \\
\hline & Public Consumption & $1 \div 3.8$ & 0.11 & & In:eress Pavments & $169 ! 6$ & $0.0 ; 2$ \\
\hline & Investoment & $36 \div 8$ & 0.38 & & Transicets \& Subsidies & 266.99 & $\{1,1 ; 3$ \\
\hline & Expcirts & $2233 . \bar{C}$ & $0.3 j$ & & Capiad Expendituse & +16.201 & 0.64 \\
\hline & Imporss & $2 ! 16.4$ & $0.2 !$ & & Ficcal Balanke & $-2+301$ & 013 \\
\hline 2 & Iax Revenue & YLan (BLN) & Output $=1$ & 4 & Balance of Payments & Ywan (BLN) & Output - - \\
\hline & Sales \&xcise Tux & 1133.56 & 0.2 & & Exprers-Impirts & 281.56 & 06 \\
\hline & Innose Inritts & 133.1 & []. (i) : & & Net Profits \& Dividends & 3079 & (0)!? \\
\hline & Explst Duties & (j.) (1) & (0.ìi) & & Inceres: Paymonts & $0.0 !$ & () (I); \\
\hline & Palyroll Tax & 200.0 & 0.02 & & Nice Private Transters & (0) & $0 . x^{\prime}:$ \\
\hline & Pcrsultal acome $\mathrm{Tax}$ & 20.0 & (0) 30 & & Net Oficlal lialsters & 0.0 & 1) (3:i: \\
\hline & Capial Tuconse liax & 33.3 & $(6)$ & & CLeren: Aciound Balanket & litul & $0,1: 3$ \\
\hline & livital & 1539.32 & $0 . ! ! 5$ & & Extcrri,1] $0 \mathrm{dx}$ & 223943 & (i) $\vdots$ \\
\hline & & & & & Detet Scrvise Paynotis & $(194.98$ & (1) \\
\hline
\end{tabular}

\section{Government Budget Deficit}

$$
B D-T-p_{1} G \cdot p_{4} \text { transfer - (exchange rate)(forcign transier) }
$$

\section{* Parameters}

- Policy Barriers: $\pi$

- Barriers tos TFP improvement: $-\frac{1}{(1+\pi)}$

IABIE A.2. DATA-ChINA, 2001 


\section{Benchmark Equilibrium}

Table A.3. parameter Values and Evaluated Equatiuns

\begin{tabular}{|c|c|c|c|c|}
\hline \multicolumn{2}{|c|}{ Parameter Values } & \multicolumn{3}{|c|}{ Evaluated Equations } \\
\hline Elasticity, CLT (st) & $1.99^{\circ}$ & \multirow{5}{*}{ Real } & CET Transformation Function & 1.00 \\
\hline Elasticity, $\mathrm{CES} / \mathrm{Q}(\mathrm{sq})$ & 0.75 & & CES Composite Ciommodity & 0.99 \\
\hline Policy Bartiers (pi) & 0.35 & & Aggregate Domestic Demand & 0.99 \\
\hline \multicolumn{2}{|l|}{ Calibration } & & Relative Supply Ratio (E/D) & 0.30 \\
\hline Scale Factor: CET & 2.19 & & Relative Dernand Rario (M/D) & 0.29 \\
\hline Pruduct Share, CET & 0.65 & \multirow{4}{*}{ Nominal } & Ciovernment Reventue & 0.16 \\
\hline Barricess to TFP & 0.14 & & Tosal Incume & 1.01 \\
\hline - for C.ET & 1.51 & & Savings & 0.50 \\
\hline Scale Factor, CES/Q & 1.79 & & Consumption Function & $0.4 j$ \\
\hline \multirow{10}{*}{$\begin{array}{l}\text { Produce Share, CESQQ } \\
\text { - for CES }\end{array}$} & 0.31 & \multirow{6}{*}{ Prices } & Import Prict & I. .00 \\
\hline & 0.33 & & Export Price & !.00 \\
\hline & & & Domustic Sales Price & 1.12 \\
\hline & & & Output Price (GDP Deflator) & 1.00 \\
\hline & & & Compositc Commodiry Price (CPI) & 1.00 \\
\hline & & & Numeraire (Exclange Rate) & 1.00 \\
\hline & & \multirow{4}{*}{$\begin{array}{l}\text { Eyuilibrium } \\
\text { Cimditions }\end{array}$} & Dornestic Guods Market & 0.00 \\
\hline & & & Cumpositc Goods Market & 0.00 \\
\hline & & & Current Account Baliace & -0.01 \\
\hline & & & Government Budget Constraint & 0.01 \\
\hline
\end{tabular}

Table A.4. A BENChMark EquILIBRIUM

\begin{tabular}{|c|c|c|c|c|c|c|}
\hline Exogenous Variables & \multicolumn{2}{|c|}{ Base :Current } & \multirow{2}{*}{ Export Good (E) } & \multirow{2}{*}{$\begin{array}{r}\text { Base } \\
0.23 \\
\end{array}$} & \multicolumn{2}{|c|}{ Current Cu/Ba } \\
\hline World Price of Impors (apm) & 0.94 & 0.94 & & & 0.23 & 1.00 \\
\hline World Price of Exporss $\langle\mathrm{upc}$ \} & 1.00 & 1.00 & Import Goxd (M) & 0.22 & 0.22 & 1.00 \\
\hline Import Tariffs $(\mathrm{km})$ & 0.07 & $0,0 ?$ & Suppiy of Dumestic Good (Ds) & $0.7 ?$ & 0.77 & 1.00 \\
\hline Export Duties (te) & 0.00 & 0.00 & Demand of Domesric Groxl (Dd) & 0.77 & 0.77 & 3.00 \\
\hline Indirect Taxes (cs: & 0.12 & 0.12 & Supfiy of Composite Grod (Qs) & 0.99 & 0.99 & 1.00 \\
\hline Direct Iaxes (ty) & 0.02 & 0.02 & Demand of Composite Goox (Qd) & 0.99 & 0.99 & 1.00 \\
\hline Savings Race (sy) & $0.51 \mathrm{i}$ & 0.51 & Tax Revenue (TAX) & 0.16 & 0.6 & 1.00 \\
\hline Government Consumption (G) & $0 . ! 2$ & 0.12 & Tota! Incone (Y) & 1.02 & l. (U] & 1.003 \\
\hline Grvernment Trarsfers (Tr) & 0.03 & 0.03 & Aggrigate Savings (S) & 0.50 & 0.50 & 1.00 \\
\hline Foreign Grants (F) & $0.000^{\dagger}$ & 0.00 & Consimprion (CON) & 0.43 & 0.43 & 1.00 \\
\hline Nec Private Remittances (Ré) & -0.01 & -0.01 & Import Price (pn) & 1.00 & 1.00 & 1.001 \\
\hline Forcign Savng (B) & .0 .01 & .0 .01 & Export Price (pe) & $1 .(10)$ & 100 & 1.00 \\
\hline Ot:put $(\mathrm{X})$ & 1.001 & 1.00 & Sales Price (pr) & 1.12 & 1.12 & 100 \\
\hline & & & Compasitc Goud Price CPi (pq) & 1.00 & 1.00 & 1.00 \\
\hline & & & Output Price-GDP Deflator (px) & 1.00 & 1.60 & 1.00 \\
\hline & & & Domestic Goxs: Prise (rot) & 1.00 & 1.00 & 1.00 \\
\hline & & & Exchange Rate (xr) & 1.00 & 1.60 & 1.00 \\
\hline & & & Investment (l) & 0.31 & 0.14 & 1.31 \\
\hline & & & Government Savings $(\mathrm{Sg})$ & -0.01 & -0.01 & 1.00 \\
\hline & & & W:alras Law (Investment-Savings) & -0.12 & 0.60 & \\
\hline
\end{tabular}




\section{Counterfactual Equilibria}

\section{1) Short Run (Impact) Effect (50 Percent Reduction in the Tariff Collection Rate)}

Tabif A.5. Parameter Valles and fvalliated equations

\begin{tabular}{|c|c|c|c|c|}
\hline \multicolumn{2}{|c|}{ Parameter Values } & \multicolumn{3}{|c|}{ Evaluated Equations } \\
\hline Elasticity, (ET (st) & 1.95 & \multirow{5}{*}{ Real } & CET Transformarion Function & 100 \\
\hline Ejasticity, CES Q (sq) & 0.75 & & CES Composite Conmodicy & 0.99 \\
\hline Policy Barriers (pi) & 0.35 & & Aggregate Domestic Demand & 0.99 \\
\hline \multicolumn{2}{|l|}{ Calibration } & & Reliative Supply Ratio (E/D) & 0.31 \\
\hline Scale Factor, CET & 2.19 & & Rclative Demand Ratio (M/D) & 0.30 \\
\hline Pruduct Share. CET & 0.65 & \multirow{4}{*}{ Nominal } & Government Revenue & 0.55 \\
\hline Barricrs to TFP & 0.74 & & lotal lncorne & 1.01 \\
\hline - for CET & 1.51 & & Savings & 10.49 \\
\hline Scale Factor, CFS/Q & 1.79 & & Consunption Function & 0.43 \\
\hline Product Sharc, CES!Q & 0.31 & \multirow{6}{*}{ Prices } & Import Price & 0.97 \\
\hline \multirow[t]{7}{*}{ - for CES } & 0.33 & & Exyourt Price & 1.00 \\
\hline & & & Domestic Sales Price & 1.10 \\
\hline & & & Output Price (GDP Deflator) & $0.14)$ \\
\hline & & & Compositc Commodity Price (CPI) & 0.98 \\
\hline & & & Numeraire (Exchange Rate) & 1.00 \\
\hline & & \multirow{4}{*}{$\begin{array}{l}\text { Equilibrium } \\
\text { Conditions }\end{array}$} & Demestic Gouds Marker & 0.00 \\
\hline & & & Composite Goods Marke: & 0.00 \\
\hline \multirow{2}{*}{ 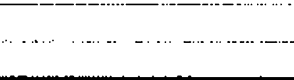 } & & & Cusrent Account Balance & 0.00 \\
\hline & & & Government Budget Constrantht & -0.02 \\
\hline
\end{tabular}

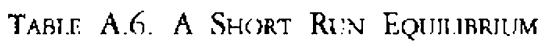

\begin{tabular}{|c|c|c|c|c|c|c|}
\hline Exogenous Variables & Base & Current & Endogenous Variables & Rase & Current & $\mathrm{Cu} / \mathrm{Ba}$ \\
\hline World Price of Imports (wigm) & 0.94 & $0.9 / 4$ & Export Good (E) & 0.23 & 0.23 & 02 \\
\hline World Price of Exports (wpe) & 1.00 & 1,00 & Iniport Good (M) & 0.22 & 0.23 & .02 \\
\hline Import Tarifs (tm) & 0.03 & 0.09 & Supply of Domessis Good (Ds) & 0.77 & 0.77 & 0.99 \\
\hline Export Dnties $(t c)$ & 0.00 & 0.00 & Demand of Domestik (ioxd (Dd) & 0.77 & 0.7 & (1).99 \\
\hline Indirecr Taxes (tss) & 0.12 & 0.12 & Supply of Composite Good (Qs) & 0.99 & 0.45 & 00 \\
\hline Direct Taxes (ty) & 0.02 & 0.02 & Demand of Composite Gind (Qd) & 0.99 & $0.9 \%$ & .00 \\
\hline Savitugs Rate (sy) & 0.51 & $0.5:$ & Tax Revenue (TiX) & 0.15 & 0.15 & 1999 \\
\hline Governmenr Consumption (G) & 0.12 & 0.12 & Tixal Imome (Y) & 1.022 & 3.01 & (j.99) \\
\hline Government Transfers (Tr) & 0.03 & 0.03 & Aggregate Savings (S) & 0.39 & 049 & 1.99 \\
\hline Foreign Grants (Ft) & 0.00 & 0.00 & Consumption (CON & 0.43 & 0.43 & ?.01 \\
\hline Net Private Remittances $(\mathrm{R})$ & -0.01 & $-0.16 !$ & Import Price (pת)i & 1.00 & 0.97 & (3) ? ? \\
\hline Foreign Saving (B) & 0.00 & 0.000 & Expon Price $(\underline{x})$ & 1.60 & $\operatorname{lok} 3$ & $! 00$ \\
\hline Otitsur $(X)$ & I.UO) & 1.00 & Salcs Price (pt) & 1.12 & 1.16 & 0.98 \\
\hline \multirow{3}{*}{ 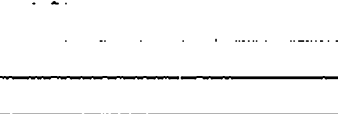 } & & & Compusite Goxid Price (PI (pq) & 1.00 & (1) & 38 \\
\hline & & & Ourpul Price-GIPP Deilatus igx) & 1.60 & ij. (j) & (y) \\
\hline & & & Donestic Gooni Price (pd) & 1.(0) & $0 \%$ & 89 \\
\hline \multirow{4}{*}{ 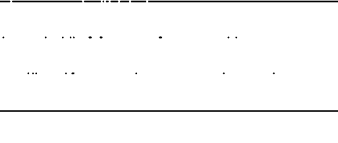 } & & & Exchauge Rate $(\mathrm{xr})$ & 1.60 & $i .0 x$ & 1.06 \\
\hline & & & Investment (1) & 0.3 & j.14 & 1.36 \\
\hline & & & Governmear Savings (sg & -10.02 & $-010 ?$ & 9.96 \\
\hline & & & Walras Iaw (Invescment-Sawings) & -0.11 & (j.0.) & \\
\hline
\end{tabular}




\section{2) Short-to-Medium Run Effect (Tariff Reform and 50 Percent Increase in Capital Inflow)}

Table A.7. Parameter Values and Evaluated EQuations

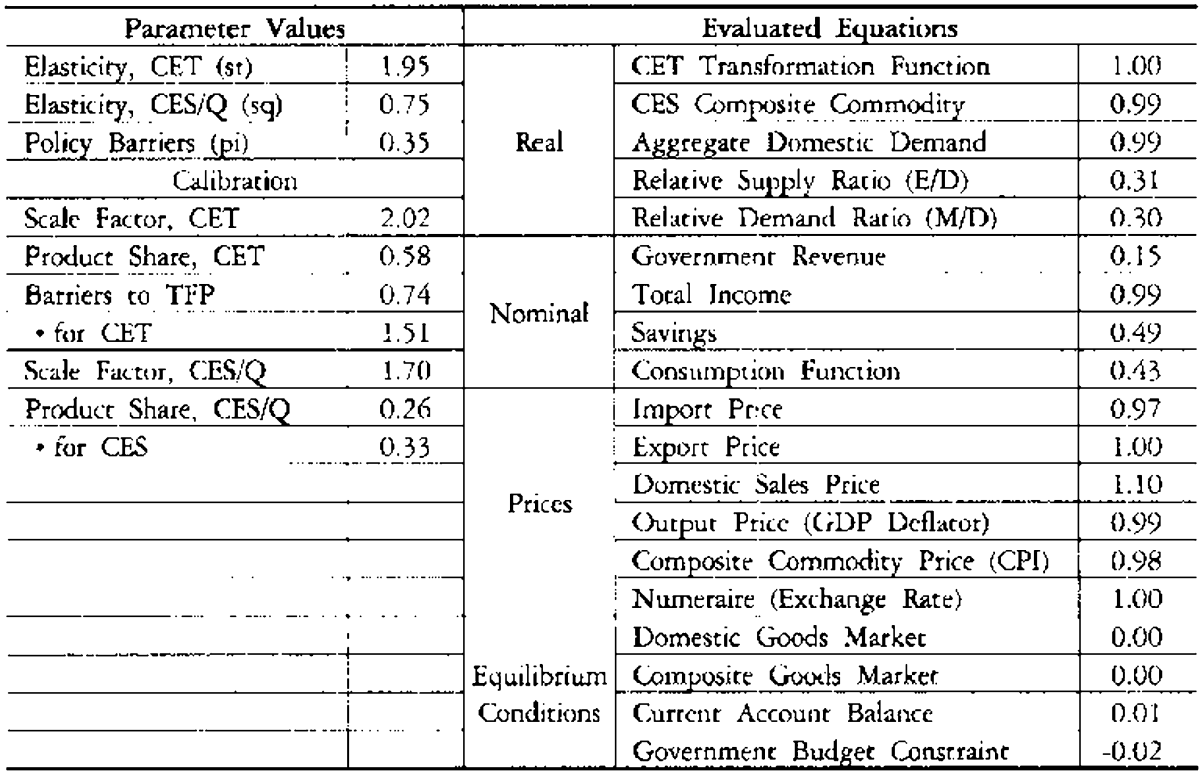

TABIE A.8. A SHORT-TO-MEdIJM RLN EQuhlirium

\begin{tabular}{|c|c|c|c|c|c|c|}
\hline Exogenous Variables & Base & Current & Endogenous Variables & Base & Current & $\mathrm{Cw} / \mathrm{B}$ \\
\hline World Price of lmports (wpm) & 0.94 & 0.94 & Export Good (E) & 0.23 & 0.23 & 1.02 \\
\hline World Price of Exports (wpt) & 1.00 & 1.00 & Inport Good (M) & 0.22 & 0.23 & 1.02 \\
\hline Import Tarifts $(\mathrm{tm})$ & 0.03 & 0.03 & Supply of Domestic Good (Ds) & 0.77 & 0.77 & 0.99 \\
\hline Export Dutics (tc) & 0.00 & 0.00 & Detriatid of Domestic Cood (Dd) & 0.77 & 0.77 & 0.99 \\
\hline Indirect Taxes (ts) & 0.12 & 0.12 & Supply of Composite Frood (Qs) & 0.99 & 0.99 & 1.00 \\
\hline Direct Taxes $(t y)$ & 0.02 & 0.02 & Demand of Compesite Good (Qd) & 0.94 & 0.99 & 1.00 \\
\hline Savings Rate (sy) & 0.50 & 0.50 & Iax Revenue (TAX) & 0.15 & 0.15 & 0.99 \\
\hline Government Consurnption (G). & 0.12 & 0.12 & Total Income $(r)$ & 1.01 & 0.99 & 0.99 \\
\hline Government Transfers $(T r)$ & 0.03 & 0.03 & Aggregate Savings ( $\mathrm{S}$ ) & 0.49 & 0.49 & 0.99 \\
\hline Foreign Gtants $(\mathrm{Ft})$ & 0.00 & 0,00 & Consumption (CON) & 0.43 & 0.43 & 1.01 \\
\hline Net Private Rernittances $\{\mathrm{Re}$ \} & -0.03 & 0.03 & $\operatorname{lmport}$ Price $(\mathrm{pm})$ & 1.00 & 0.97 & 0.97 \\
\hline Forcign Saving $(B)$ & 0.01 & 0.01 & Export Price (pe & 1.00 & 1.00 & 1.00 \\
\hline \multirow[t]{5}{*}{ Output $(\mathrm{X})$} & 1.00 & 1.00 & Sales Prict $(p t)$ & 1.12 & 1.10 & 0.98 \\
\hline & & & Composite Gond Price CPI $(\mathrm{pg})$ & 1.00 & 0.98 & 0.98 \\
\hline & & & Output Price-GDP Deflator (px) & 1.00 & 0.99 & 0.49 \\
\hline & & & Domestic Coond Price (pd) & i. 00 & 0.99 & $0.9)$ \\
\hline & & & Exchnuge Rate (xr) & $\$ .00$ & $! .00$ & 1.00 \\
\hline \multirow{3}{*}{ 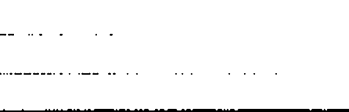 } & & & Investmient (1) & 0.34 & 19.44 & 1.30 \\
\hline & & & Governmenc Savings (Sg) & $-0.0 ?$ & -0.02 & 0.96 \\
\hline & & & Waltas Law (lnvestment-Savings) & $-0.1 !$ & 0,00 & \\
\hline
\end{tabular}




\section{3) Medium-to-Long Kun Effect (Tariff Reform, Capital Inflow, and Internal Reform)}

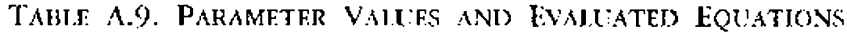

\begin{tabular}{|c|c|c|c|c|}
\hline \multicolumn{2}{|c|}{ Parameter Values } & \multicolumn{3}{|c|}{ Evaluated Equations } \\
\hline Eluscicity. CET (st) & 1.95 & \multirow{5}{*}{ Kéal } & CFT Transfortuatom Functiun & 1.04 \\
\hline Elasticity. CESYQ (s]? & 0.75 & & CFS Gomposite Commondey. & 1.26 \\
\hline Policy Barsiers (pi) & 0.35 & & ikggregate Dumestic Dentand & 1.26 \\
\hline \multicolumn{2}{|l|}{ Calibration } & & Relative Supply Reitis) (E) & 0.23 \\
\hline Sath: Pactor ClT & $\therefore(1) ?$ & & 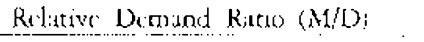 & 1922 \\
\hline Proguct Share, CET & 0.58 & \multirow{4}{*}{ Nuninal } & Government Revenue & 0.15 \\
\hline Barriers to THP & (1.).1-1 & & Totail Incone & 1.26 \\
\hline - for CET & $1.5 \mathrm{i}$ & & Savings & 0.63 \\
\hline Scalls lactor CLSQQ & $! .70$ & & Consumption liuncrion. & 4.56 \\
\hline Prociut Slitre $C E S / Q$ & (1) 26 & \multirow{6}{*}{ Prices } & lengerst Price & $(1))^{-}$ \\
\hline - for CES & (1).33 & & Fxport Price & ?.oij \\
\hline & & & Domestic Sales Price & !. (i) \\
\hline \multirow{7}{*}{. } & ". & & (output Price (GDP Deflator) & 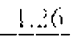 \\
\hline & & & (onupowire (ximmentity Prite (CPI) & 0.98 \\
\hline & & & Vumeraiete (Exchange Rate) & (...ij \\
\hline & & \multirow{4}{*}{$\begin{array}{l}\text { Equilibriumn } \\
\text { Condisions }\end{array}$} & Dornestic Gouds Market & 0.00 \\
\hline & & & Conposite Goods Market & $0 .(j !)$ \\
\hline & & & Currene Acciount Balinince & $(b)(0)$ \\
\hline & & & Government Budgct Construint & -0.01 \\
\hline
\end{tabular}

Table A.10. A MedITM-TO-Lonti RIN EQtiltibril M

\begin{tabular}{|c|c|c|c|c|c|c|}
\hline Exoygenous Variables & Base & Current: & Fndogenous Variahles & Base & Current: & $\mathrm{C}_{u_{i}} \mathrm{~B}_{\mathrm{a}}$ \\
\hline Worid Price of Imports (wens) & 0.94 & 094 & Export Good (E: & 0.23 & 0.23 & 1.02 \\
\hline World Price of Expors (wret & 1.6ij & 1.100 & Iropure (ionis (B.1) & 0.22 & 0.23 & $1 .(12$ \\
\hline Impsirt Tarifls (tm) & $00 \mathrm{~s}$ & (i).03 & Su:ply of Demosete (ionk (D)s! & $1.0 \%$ & .04 & 1.00 \\
\hline Export Dities (te) & 0.00 & 0.60 & Demand of Domestic Gowed (Dd) & $1.0 \%$ & $\therefore 013$ & 160 \\
\hline Indirest Taxes (ts) & $0.0 !$ & (10) & Supply of Compusite Goos (Qs: & 1.26 & $: .26$ & 1110 \\
\hline Direc: Taxes $(t y)$ & 0.02 & 1) 18 & Demand of Comnosite Gond i(l) & 1.26 & 26 & 1.00 \\
\hline Savicys Ratc Sy) & 250 & 0.50 & 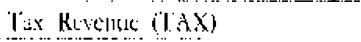 & 0̈.15 & 6.15 & $10 \overline{10}$ \\
\hline Giverenment Const:mprion $\langle\overline{G i}$ & 913 & i).13 & Tural Incenme fYi & 1.01 & $\therefore 6$ & 1.25 \\
\hline Government Tansjers $(\mathrm{Tr})$ & 20 & 0,03 & 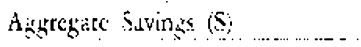 & if. 19 & 65 & 1.27 \\
\hline Foregn Grants \&fi & 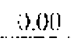 & 100 & Comsumption (Cov) & $\overline{(j .74}$ & 6.56 & 1,27 \\
\hline Net Private Retuietantes iRe: & -516 & $-(5.1133$ & Impinare Price $\{p m\}$ & 1.00 & $0 \% ?$ & $0.9 ?$ \\
\hline Forcho Saving (B) & $20)$ & 6.00 & Fxport Price in: & !oü! & !) & Iint \\
\hline \multirow[t]{2}{*}{ Qutfult $(\bar{X})$} & 1.06 & 1.00 & Stics Price ipt) & ! (1) & 0.08 & $0: 8^{2}$ \\
\hline & & & 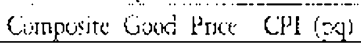 & !.10u & $\therefore$ & 1).j8 \\
\hline & & & 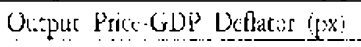 & 1.00 & 120 & 1.26 \\
\hline & & & 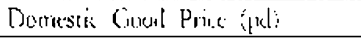 & . .090 & (;) & $(1)$ \\
\hline & & & Exchange Rate: $\{x=1$ & (.ji) & 100 & {$[:(j)$} \\
\hline & & & Iriestrnctur :1! & 0.55 & (: 58 & 118 \\
\hline & & & Guyernment 3aytrys $\overline{s p i}$ & i). & $-(;) ; 1$ & $0(1)$ \\
\hline & & & 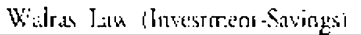 & (i) $1:$ & s.oit & \\
\hline
\end{tabular}




\section{APPENDIX B: ESTIMATION OF THE GRAVITY EQUATION}

\section{Data}

Data have been collected for the group of seventeen countries from various sources including World Economic Ouclook 2002, International Financial Statistics, World International Trade Statistics, and the Penn World Table 5.6. The data set does not include all the APEC members. Four economics, Bnunei Darussalam, Papua New Guinea, Russia, and Vict Nam, are excluded form the data set due to the paucity of information.

The source of the data on bilateral trade flows $X^{i j}\left(M^{i j}\right)$ is the Trade and Production Database whose construction was supporced by the World Bank. The bilateral trade flows data are reported in current U.S. dollars. The data on variations in the exchange rates ( $\triangle X R / X R$ ) with dollar come from the Penn World Table version 5.6. The exchange rates data are extended from 1993 to 1999 using Federal Reserve Statistical Release G.5A. For the other variables, proxies are used. The c.i.f.(cost, insurance and freight) / f.o.b.(free on board) factor (transportation costs) is represented by the bilatetal distance between the cajuital citics measured in kilometers (DT) whose source is Jon Haveman's Useful Gravity Model Data set. The distance data combined with those on the exchange rate variarions are used to represent transport costs (or trade barriers). The data on cross-country differences in the price level $\left(P, P^{*}\right)$ with its base in 1985 and gross domestic product $(G D P, G D P$ ) in U.S. dollars come from the World Fconomic Outlook Database 2000 compiled by the lnternational Monetary Fund.

Each member's data set covers a different time span: the end year is 1999 (except for lndonesia), but the beginning year difters. The number of the observations does not always equal the product of the time span and the number of the countries due to the omitred observations. The panel data scts are not necessarily balanced. Average exports and imports of the bilateral rrade flows between the country concerned and the other members vary widely from 70 million LSS\$ and 100 million US\$ (Peru) to 11 billion LS\$ and 17 billion US\$ (LSA).

The Grubel-Lloyd indices are calculated from the data on the trade flows between country pairs that are included in the data set. Calculated at the four-digit SIIC, these indices vary across countries from the low of less than 4 percent for Peru to the maximum of 56 percent for Hong Kong. The Grubel-Lloyd indices of Australia (0.244), China (0.211), Kurea (0.223), and Taiwan (0.213) are near the average, while those of Malaysia (0.261), Singapore (0.320), the United States (0.324), and Hong Kong (0.561) are above the average. It is important to note that these values in Table 5 are different from those in Table 4 , which has been based on the data of all 21 members instead of 17 members included in the data set.

Foreign GDP denotes the average income of the trading partners of the country concerned. The average incomes of the trading partners vary from 754 billion US\$ (Mexico) and 729 billion US\$ (China) to 304 billion US\$ (U.S.A.) and 429 billion 
US $\$$ (Japan). However, home GDP differs vastly, reflecting the different stages of economic development among the member economies.

Average per capita GDP is highest in the United States $(21,441$ US\$), followed by Japan $(21,318$ US\$) and Canada $(16,859$ US\$). At the uther extreme, China (468 US\$), Indonesia (682 US\$), and the Plitipprines (748 US\$) are among the countries with the lowest per capita GIDP.

Per capita GDP has heen used to make a proxy for. Under the assumption that technology is identical across countries, the average of per capita GDPs in the region has been used as the "common" equilibrium scale of the production for each country. Given, it is easy to derive the equilibrium number of varieties produced in each country.

Peru has an exceptionally high average inflation rates due to hyperintlation it experienced during the $1988-91$ period 667 percent in $1988,3,399$ pencent in 1989 , 7,486 percent in 1990, and 410 percent in 1991). Mexict) (46 percent), Chile (16 percent), Indonesia (13 percent) and the Philippines (12 percent) are among the other high inflacion economies.

In terms of bilateral distances, Peru $(13,797 \mathrm{~km})$ and Chile $(13,725 \mathrm{~km})$ are the most "remote" economics. Capital per worker is highest in Canada (38,239 US\$), followed by Australia (36,428 US\$), the United States of America (33,504 US\$), New Zealand (32,899 US\$), and Japan $(32,85$ ? US\$). The Philippines (3,787 US\$), Thailand (4,819 US\$), and Peru (8,972 US\$) are among those countries with the lowest capical-labor ratios.

\section{Estimation}

The estimation strategy is to specify a bilateral trade flow cquarion based on the gravity equation derived above and augmented by additional considerations. Both export flows and import flows are separately estimated and compated. The basic regression equation is given by as follows.

$$
\begin{aligned}
\ln X^{i j}= & \beta_{1} \ln \left(Y_{i}+Y_{i}\right)+\beta_{2} \ln \left(S_{i} S_{j}\right)+\beta_{j ;} \ln \frac{Y_{j}}{q P_{j}} \\
& +\beta_{1} \cdot \frac{\ln (D T)}{(1+\Delta X R / X R)}+\beta_{i} \frac{P_{i}}{P_{j}}+\varepsilon
\end{aligned}
$$

The first term appearing in the equarion $(B-1)$ represents the effect of the "market expansion." The second term represents the "size" dispersion effect, which reflects the effects of the IRS-based trade. The third term is in the above equation supposed

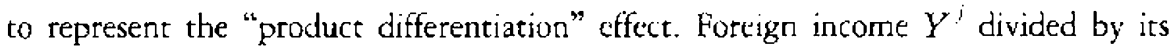

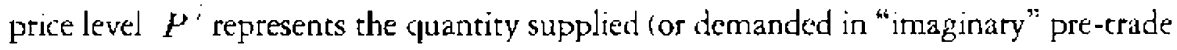
equilibrium) of the "aggregate" differentiated product, which gives the equilibrium number of varieties when divided by $q$, the equilibrium quantity of the "supposedly identical" differentiated product. A large value of this term means that the foreign 
country can provide its demand for differentiated goods relatively sufficiently from the local suppliers, needing relatively few imported varieties from the home country.

The fourth term in the equation denotes the transport cost term. It is approximated by the product of bilateral distances and exchange rate variation. Variations in the exchange rates are included as part of a transport cost regressor to represent the "price effect."

The fifth term comes directly from the relative price ratio term, which reflects the pattern of comparative advantage. It can be inferred from the standard tradc model that exports are expected to decrease as the ratio of the home price to the foreign price increases, in accordance with the prediction of the comparative advantage.

One thing to note here is that the third and the fifth terms should have the opposite signs. To sce why they are inversely related to each other in explaining bilateral trade flows, consider the following. While an increase in the demand for variety (that is, a decrease in the value of the third term) in foreign country is likely to raise exports, an increase in production costs (cxporter's price) reduces exports. The larger the number of the variety equilibrium is, the lower is the price of each variety. If the size of the market becomes larger, the number of the variety that can be produced increases. However, the net increase in the number of the variety in a country with a larger local market is less than that in a smaller one, because the former has already been producing more varieties than the latter. As a result, the larger the number of locally produced varieties is, the smaller is the reduction in the local equilibrium price. Thus, if exports based on the product differentiation to a larger market decrease, then exports based on comparative advantage (relative price) increase. If the force of "product-differentiation-based" trade prevails, the force of "comparative-advantagebased" trade will diminish. That is, the negative sign of the number of the variety term should be accompanied by the positive sign of the relative price term. These two forces are expected to work in opposite direction. For example, if trade based on product differentiation prevails, then trade based on comparative advantage should get smaller, meaning that the relative price term has a positive sign. In this regard, equation (B-1) is set up with a view to estimating how IRS-based trade and comparative advantage-based trade are related to each other.

Another form of the gravity equation to be used on the import data is expressed as follows.

$$
\begin{aligned}
\ln M^{i j}= & \beta_{1} \ln \left(Y_{i}+Y_{j}\right)+\beta_{2} \ln \left(S_{i} S_{i}\right)+\beta_{3} \ln \frac{Y_{j}}{q P_{i}} \\
& +\beta_{4} \ln (D T)\left(1+\frac{\Delta X R}{X R}\right)+\beta_{5} \frac{P_{j}}{P_{i}}+\varepsilon
\end{aligned}
$$


Table B.1. Gravity Equation $\mathrm{X}_{\mathrm{I}} \mathrm{j}$

\begin{tabular}{|c|c|c|c|c|c|c|c|c|}
\hline$x_{i j}$ & & $\log \left(Y_{i}+Y_{j}\right)$ & $\log (\mathrm{SiSj})$ & $\log \left(\mathrm{Y} ; \mathrm{Pj}^{*} \mathrm{q}\right)$ & $\left(\begin{array}{c}\log \left(\mathrm{T}_{\mathrm{ij}}\right) / \\
(1+\Delta \mathrm{XR})\end{array}\right.$ & $\log (\mathrm{Pi} / \mathrm{Hi})$ & Constant & $\begin{array}{l}\text { Adij R2 } \\
\text { Sample }\end{array}$ \\
\hline \multirow{2}{*}{ Auscralia } & Coveft. & $\therefore 46$ & 1.02 & -0.13 & 0.00 & 0.10 & -6.31 & 0.55 \\
\hline & t-ratio & 22.83 & 5.98 & $-(2.93$ & $-\therefore .98$ & $\therefore 86$ & $-3 . i j y$ & 357 \\
\hline \multirow{2}{*}{ Cancidis } & Coctf & 1.11 & 0.46 & 0.45 & $0.00)$ & -1.42 & -14.77 & $0.5 ?$ \\
\hline & t-ratios & 19.96 & 3.84 & 47 & -0.45 & 4.22 & -8.74 & $\therefore 4$ \\
\hline \multirow{2}{*}{ Chite } & cosft. & 2.23 & 0.75 & 0.35 & 0.00 & 0.37 & 79 & 0.83 \\
\hline & trativ & 1533 & 3.10 & 1.76 & 0.41 & 8.81 & -2.89 & $3 i j{ }^{\circ}$ \\
\hline \multirow{2}{*}{ Hong Kıng } & Cixit. & 132 & 1.50 & $0.3 ;$ & {$[3,(10)$} & -40 & $-10\} .16$ & $0.9 \%$ \\
\hline & (1-ratio & 30.01 & 13.12 & 3.23 & $i .14$ & -277 & $-(1)+8$ & $y_{1}^{-1}$ \\
\hline \multirow{2}{*}{ Indonesia } & Coeff. & 326 & 1.43 & -1.26 & $0.0(4)$ & 1.41 & 2.12 & $0.6 ?$ \\
\hline & $t$-ritio & 12.05 & 3.15 & -4.18 & $-(f, 1), j$ & 4.4 & $0.5 ?$ & 34 \\
\hline \multirow{2}{*}{ Jappist } & Coctt. & $1.1 j$ & $1.3:$ & -0.64 & 0.00 & $0.6 \%$ & .58 & $0.5:$ \\
\hline & t-riacio & 28.47 & $13.8 i j$ & $-6 y !$ & $-\therefore 88$ & -.19 & $4(2)$ & 4.18 \\
\hline \multirow{2}{*}{ Kurtat } & Corff. & 1.78 & 1.60 & -014 & 0.00 & 0.05 & -7.10 & (j) \\
\hline & t-ratio! & 16.14 & 3.55 & -0.73 & -1.27 & 1.24 & -2.22 & $4 i 6$ \\
\hline \multirow{2}{*}{$M(x) c 0$} & Coxte. & 2.06 & 1.25 & -0.11 & i..10 & 0.10 & -11.66 & 0.82 \\
\hline & t-tatio & 9.97 & 3.46 & $-10.5 ?$ & $-i j .85$ & 0.48 & $-3 .-1$ & $2 \% ?$ \\
\hline \multirow{2}{*}{ Malaysia } & costff. & 2.58 & 1.35 & $-(1.7 \overline{7}$ & 0.00 & 0.63 & 0.25 & 0.45 \\
\hline & t-ration & 3608 & 6.42 & -507 & $-1.5 \%$ & $40 ?$ & (1). 11 & 374 \\
\hline \multirow{2}{*}{. Vẹ Zealanó } & Cokff & 1.20 & 0.48 & (c) 1.1 & 0.00 & 0.1 .4 & 5.17 & 890 \\
\hline & (2- rartio! & 19.75 & 279 & $-\therefore 29$ & 0.10 & 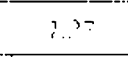 & -3.38 & 35 \\
\hline \multirow{2}{*}{ Peru } & coctit. & 1.66 & 0.30 & $0.9 ?$ & 0.00 & $0 ? 3$ & -1.4 .30 & $0.6(0)$ \\
\hline & t. ratlo & $\therefore .84$ & 0.64 & (j.6!) & $\therefore(1)$ & $-i 1.56$ & $\therefore 3$ & $+i j:$ \\
\hline \multirow{2}{*}{ Philippines" } & Cutit. & 1.81 & 2.13 & 0.87 & 0.101 & 0.40 & & 1.00 \\
\hline & tratio & 15.08 & 3.34 & 3.39 & -0.55 & -3.39 & & $\because 2$ \\
\hline \multirow{2}{*}{ Sirsgapore" } & Cuette & .19 & 1.21 & (is) & 0.00 & $-(1.61$ & & 0.96 \\
\hline & teritio! & $2 ! 42$ & $: 2.19$ & +.33 & $-\bar{i} .(0 j$ & $\therefore 33$ & & $\vdots: 7$ \\
\hline \multirow{2}{*}{ Ihrastand" } & Coweff & 2.29 & 0.45 & .1 .34 & $i, 0)$ & 1.20 & & 0.85 \\
\hline & t-atio & 23.01 & 131 & -9.95 & $-(1,29$ & 4.26 & & 4 \\
\hline \multirow{2}{*}{ 'Taाwan' } & Coiff. & 1.21 & 0.63 & (j47 & 600 & .0 .18 & & 0.45 \\
\hline & t-ratiul & $.31 ; .64$ & 4.114 & 3.90 & 0.15 & $\therefore .8$ & & ; \\
\hline \multirow{2}{*}{$\mathrm{CS}$} & $\cos t \theta^{\circ}$ & $1.3 ?$ & 1.49 & - (1) 68 & 0.000 & 070 & $\therefore 6$ & (1.98 \\
\hline & (1- toltiti) & 41,78 & 11.34 & 4.90 & $-1.4 i$ & $5.12,4$ & 256 & ئ日 \\
\hline
\end{tabular}


Table B.2. Gravity eqlation My

\begin{tabular}{|c|c|c|c|c|c|c|c|c|}
\hline $\mathbf{M i j}$ & & $\log (X i+Y$ & $\log (S i S j)$ & $\log \left(Y^{i} / P^{i}{ }^{*} q\right)$ & $\begin{array}{c}\log (\mathrm{Tij})^{*} \\
(1+\Delta \mathrm{XR} / \mathrm{XR})\end{array}$ & $\log (\mathrm{Pj} / \mathrm{Pi})$ & Constant & $\mid \begin{array}{l}\text { Adj R2 } \\
\text { Sample }\end{array}$ \\
\hline \multirow{2}{*}{ Auscralia } & Cixtl. & 1.36 & $0.3 i$ & -0.76 & 0.00 & 0.82 & 4.44 & 0.95 \\
\hline & $t$-ratio & 17.94 & 2.42 & .2 .15 & -1.40 & 2.32 & 0.69 & $35 ?$ \\
\hline \multirow{2}{*}{ Canada } & Coeff. & 1.81 & $0.5 !$ & -0.74 & 0.00 & 0.73 & 1.25 & 0.93 \\
\hline & $\mathrm{t}$-racio & 14.21 & 2.59 & -1.76 & -1.133 & 1.75 & 0.76 & 374 \\
\hline \multirow{2}{*}{ Chilc" } & Coeff. & 2.66 & 2.49 & .0 .85 & 0.00 & 0.78 & & 0.70 \\
\hline & t-racio & 12.31 & 4.72 & -1.87 & 0.06 & 1.71 & & 308 \\
\hline \multirow{2}{*}{ Ilong Kong } & Coeff: & 1.46 & 1.47 & 0.35 & 0.00 & -0.27 & -10.79 & 0.98 \\
\hline & t-ratio & 11.95 & 11.92 & 2.35 & -1.38 & -1.04 & -2.92 & 374 \\
\hline \multirow{2}{*}{ Incionesid } & Coeff. & 1.66 & 0.83 & -0.39 & 0.00 & 0.44 & -3.31 & 0.83 \\
\hline & t-rario & 12.65 & 2.86 & -3.55 & 0.34 & 1.74 & -0.75 & 340 \\
\hline \multirow{2}{*}{ Japan } & Coeff: & 1.53 & 0.42 & 1.31 & 0.010 & 1.25 & 15.45 & 0.95 \\
\hline & r.ratios & $24.1 ?$ & 5.64 & -9.56 & -7.78 & 9.2 .5 & 7.01 & 408 \\
\hline \multirow{2}{*}{ Korea } & Coueff. & 1.71 & 3.18 & 0.18 & 0.00 & -0.21 & -12.19 & 0.80 \\
\hline & t-ratio & $5.8 ?$ & 4.22 & 0.32 & -0.37 & -0.37 & -1.50 & 106 \\
\hline \multirow{2}{*}{ Mexico } & Corff. & 3.47 & 2.42 & $-0.3 / 4$ & 0.00 & 0.45 & & 0.69 \\
\hline & r-ratio & $1: 43$ & 4.31 & $0.6 \%$ & -0.71 & 0.84 & & 297 \\
\hline \multirow{2}{*}{ Malaysia } & Cixetf. & 1.78 & 0.45 & 0.60 & 0.00 & -0.55 & -19.57 & 0.93 \\
\hline & t-ratio & 17.99 & 1.80 & $1.84^{\circ}$ & -0.78 & -1.70 & -3.92 & 374 \\
\hline \multirow{2}{*}{ New 7edand } & Coeff. & 1.33 & 1.08 & -0.86 & 0.00 & 0.90 & 5.68 & 0.92 \\
\hline & t-ratio & 15.74 & 4.69 & -3.10 & -0.43 & 2.21 & 0.88 & 357 \\
\hline \multirow{2}{*}{ Peru ${ }^{*}$} & Coeff. & 1.69 & 2.20 & -0.29 & 0.00 & 0.22 & & 0.63 \\
\hline & t-tatio & 2.96 & 2.52 & $-(0.35$ & -1.05 & 0.26 & & 401 \\
\hline \multirow{2}{*}{ Philippines" } & Cocff. & 2.17 & $2.2 \%$ & -0.62 & 0.00 & 0.62 & & 1.00 \\
\hline & t-tario & 23.74 & $6.8 ?$ & .2 .03 & -1.91 & 2.03 & & 392 \\
\hline \multirow{2}{*}{ Singapore" } & Coeff. & 1.55 & 1.29 & 0.45 & 0.00 & 0.51 & & 0.97 \\
\hline & $t$-tasios & 10). 46 & 8.16 & -1.67 & -1.22 & 1.87 & & 337 \\
\hline \multirow{2}{*}{ Thailand" } & Couff. & 1.32 & -0.09 & $1.2 ?$ & 0.00 & -1.21 & & 0.80 \\
\hline & {$[-$-ratiu } & 4.58 & -0.22 & .60 & $-2(1.0 .3$ & -1.52 & & 407 \\
\hline \multirow{2}{*}{ Taiwan } & Cigeft: & 1.63 & 0.83 & -0.05 & 0.00 & 0.06 & -8.08 & 0.95 \\
\hline & t-ratio & 2.52 & 5.81 & -19.16 & -0.50 & 0.20 & -1.80 & 393 \\
\hline \multirow{2}{*}{ US.' } & Coeff. & 1.68 & 0.37 & 0.42 & 0.00 & -0.46 & -20.06 & 0.96 \\
\hline & (-ratios & 27.17 & 3.76 & .53 & -1.50 & -1.69 & -3.64 & 3,4 \\
\hline
\end{tabular}

